NATIONAL WATER-QUALITY ASSESSMENT PROGRAM

SOURCE WATER-OUALITY ASSESSMENT

Concentration Data for Anthropogenic Organic Compounds in Ground Water, Surface Water, and Finished Water of Selected Community Water Systems in the United States, 2002-05

Data Series 268 
This page intentionally left blank. 


\section{Concentration Data for Anthropogenic Organic Compounds in Ground Water, Surface Water, and Finished Water of Selected Community Water Systems in the United States, 2002-05}

By Janet M. Carter, Gregory C. Delzer, James A. Kingsbury, and Jessica A. Hopple

NATIONAL WATER-QUALITY ASSESSMENT PROGRAM

SOURCE WATER-QUALITY ASSESSMENT

Data Series 268 


\section{U.S. Department of the Interior DIRK KEMPTHORNE, Secretary}

\section{U.S. Geological Survey \\ Mark D. Myers, Director}

\section{U.S. Geological Survey, Reston, Virginia: 2007}

For product and ordering information:

World Wide Web: http://www.usgs.gov/pubprod

Telephone: 1-888-ASK-USGS

For more information on the USGS--the Federal source for science about the Earth, its natural and living resources, natural hazards, and the environment:

World Wide Web: http://www.usgs.gov

Telephone: 1-888-ASK-USGS

Any use of trade, product, or firm names is for descriptive purposes only and does not imply endorsement by the U.S. Government.

Although this report is in the public domain, permission must be secured from the individual copyright owners to reproduce any copyrighted materials contained within this report.

Suggested citation:

Carter, J.M., Delzer, G.C., Kingsbury, J.A., and Hopple, J.A., 2007, Concentration data for anthropogenic organic compounds in ground water, surface water, and finished water of selected community water systems in the United States, 2002-05: U.S. Geological Survey Data Series 268, 30 p. 


\section{Foreword}

The U.S. Geological Survey (USGS) is committed to providing the Nation with accurate and timely scientific information that helps enhance and protect the overall quality of life and that facilitates effective management of water, biological, energy, and mineral resources ( $h t t p: / /$ www.usgs.gov/). Information on the quality of the Nation's water resources is critical to assuring the long-term availability of water that is safe for drinking and recreation and suitable for industry, irrigation, and habitat for fish and wildlife. Population growth and increasing demands for multiple water uses make water availability, now measured in terms of quantity and quality, even more essential to the long-term sustainability of our communities and ecosystems.

The USGS implemented the National Water-Quality Assessment (NAWQA) Program in 1991 to support national, regional, and local information needs and decisions related to water-quality management and policy (http://water.usgs.gov/nawqa). Shaped by and coordinated with ongoing efforts of other Federal, State, and local agencies, the NAWQA Program is designed to answer: What is the condition of our Nation's streams and ground water? How are the conditions changing over time? How do natural features and human activities affect the quality of streams and ground water, and where are those effects most pronounced? By combining information on water chemistry, physical characteristics, stream habitat, and aquatic life, the NAWQA Program aims to provide science-based insights for current and emerging water issues and priorities.

From 1991-2001, the NAWQA Program completed interdisciplinary assessments in 51 of the Nation's major river basins and aquifer systems, referred to as Study Units (http://water.usgs. gov/nawqa/studyu.html). Baseline conditions were established for comparison to future assessments, and long-term monitoring was initiated in many of the basins. During the next decade, 42 of the 51 Study Units will be reassessed so that 10 years of comparable monitoring data will be available to determine trends at many of the Nation's streams and aquifers. The next 10 years of study also will fill in critical gaps in characterizing water-quality conditions, enhance understanding of factors that affect water quality, and establish links between sources of contaminants, the transport of those contaminants through the hydrologic system, and the potential effects of contaminants on humans and aquatic ecosystems.

The USGS aims to disseminate credible, timely, and relevant science information to inform practical and effective water-resource management and strategies that protect and restore water quality. We hope this NAWQA publication will provide you with insights and information to meet your needs, and will foster increased citizen awareness and involvement in the protection and restoration of our Nation's waters. 
The USGS recognizes that a national assessment by a single program cannot address all water-resource issues of interest. External coordination at all levels is critical for a fully integrated understanding of watersheds and for cost-effective management, regulation, and conservation of our Nation's water resources. The NAWQA Program, therefore, depends on advice and information from other agencies-Federal, State, interstate, Tribal, and local-as well as nongovernmental organizations, industry, academia, and other stakeholder groups. Your assistance and suggestions are greatly appreciated.

Robert M. Hirsch

Associate Director for Water 


\section{Contents}

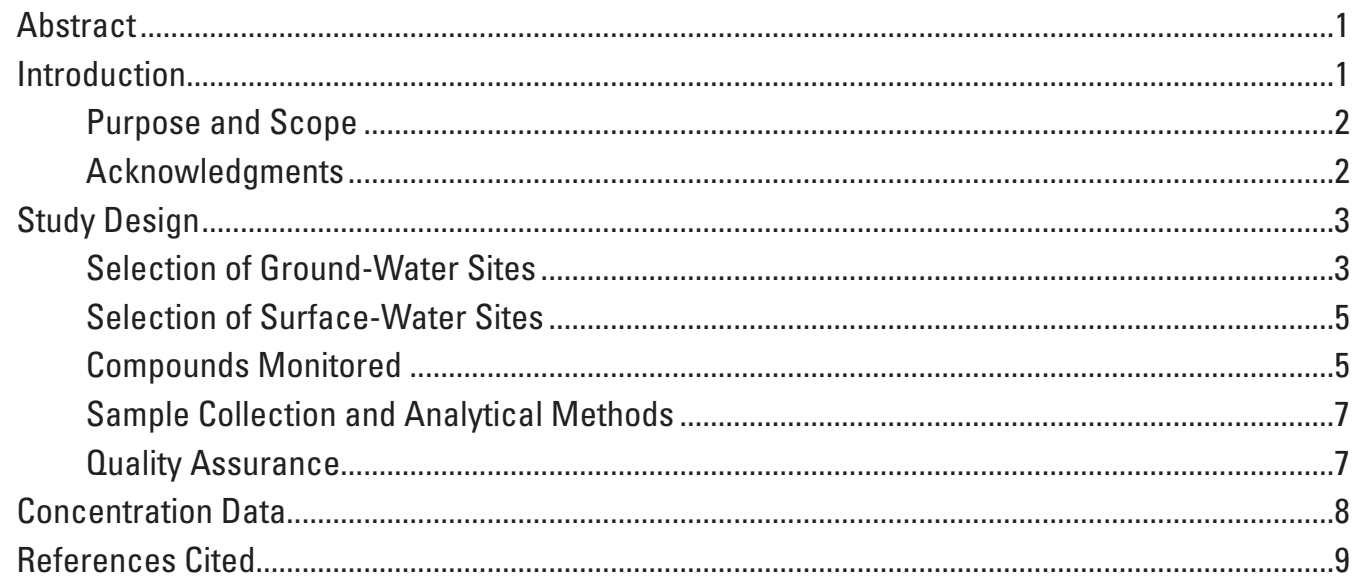

Appendix 1. Compounds analyzed in Source Water-Quality Assessment studies by primary use

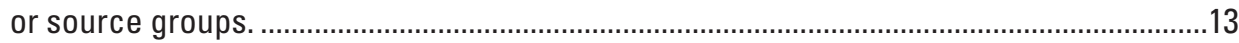

Appendix 2. Concentrations of anthropogenic organic compounds in ground water and associated finished water from community water systems and in quality-assurance samples for Source Water-Quality Assessment studies, 2002-05.

Appendix 3. Concentrations of anthropogenic organic compounds in surface water and associated finished water from community water systems and in quality-assurance samples for Source Water-Quality Assessment studies, 2002-05.

\section{Figure}

1. Map showing location of Source Water-Quality Assessment studies for which samples were collected during 2002-05..

\section{Tables}

1. Principal aquifers or other aquifers sampled for ground-water Source Water-Quality Assessment studies during 2002-05.

2. Rivers sampled for surface-water Source Water-Quality Assessment studies during 2002-05.

3. Primary use or source groups for compounds analyzed for ground-water and surface-water Source Water-Quality Assessment studies. 


\section{Conversion Factors, Acronyms, and Definitions}

\begin{tabular}{lcc}
\hline Multiply & By & To obtain \\
\hline & Length & \\
\hline kilometer $(\mathrm{km})$ & 0.6214 & mile (mi) \\
\hline
\end{tabular}

Horizontal coordinate information is referenced to the North American Datum of 1983 (NAD 83).

Concentrations of chemical constituents in water are given either in milligrams per liter (mg/L) or micrograms per liter $(\mu \mathrm{g} / \mathrm{L})$.

\section{Acronyms}

$\begin{array}{ll}< & \text { less than } \\ \text { AOC } & \text { anthropogenic organic compound } \\ \text { BTEX } & \text { benzene, toluene, ethylbenzene, and xylenes } \\ \text { CWS } & \text { community water system } \\ \text { DEET } & \text { N,N-diethyl-meta-toluamide } \\ \text { E } & \text { estimated } \\ \text { GC/MS } & \text { gas chromatography-mass spectrometry } \\ \text { HPLC/MS } & \text { high performance liquid chromatography-mass spectrometry } \\ \text { LRL } & \text { laboratory reporting level } \\ \text { LT-MDL } & \text { long-term method detection level } \\ \text { NAWQA } & \text { National Water-Quality Assessment } \\ \text { NWOL } & \text { National Water Quality Laboratory } \\ \text { OC } & \text { quality control } \\ \text { R } & \text { removed } \\ \text { SPE } & \text { solid phase extraction } \\ \text { SWOA } & \text { Source Water-Quality Assessment } \\ \text { USGS } & \text { U.S. Geological Survey } \\ \text { VOC } & \text { volatile organic compound }\end{array}$




\section{Definitions}

Terms for which definitions are provided below are presented in boldface type when first used in the text

Community water system (CWS)

A public water system with 15 or more connections and serving 25 or more year-round residents and thus is subject to U.S. Environmental Protection Agency regulations enforcing the Safe Drinking Water Act. A community water system serves a residential population, such as a municipality, mobile home park, or nursing home.

Finished water

Water is "finished" when it has passed through all the processes in a water treatment plant and is ready to be delivered to consumers.

Principal aquifer

A regionally extensive aquifer or aquifer system that has the potential to be used as a source of potable water.

Source water

Source water is the raw (ambient) water collected at the supply well or surface-water intake prior to water treatment used to produce finished water.

Source Water-Quality

An assessment activity of the U.S. Geological Survey's Assessment (SWQA) National Water-Quality Assessment Program that focuses on characterizing the quality of source water and finished water of aquifers and major rivers used by some of the larger community water systems in the United States. 
This page intentionally left blank. 


\title{
Concentration Data for Anthropogenic Organic Compounds in Ground Water, Surface Water, and Finished Water of Selected Community Water Systems in the United States, 2002-05
}

\author{
By Janet M. Carter, Gregory C. Delzer, James A. Kingsbury, and Jessica A. Hopple
}

\section{Abstract}

The National Water-Quality Assessment Program of the U.S. Geological Survey began implementing Source Water-Quality Assessments (SWQAs) in 2001 that focus on characterizing the quality of source water and finished water of aquifers and major rivers used by some of the larger community water systems (CWSs) in the United States. As used for SWQA studies, source water is the raw (ambient) water collected at the supply well prior to water treatment (for ground water) or the raw (ambient) water collected from the river near the intake (for surface water), and finished water is the water that is treated and ready to be delivered to consumers. Finished water is collected before entering the distribution system.

SWQA studies are conducted in two phases, and the objectives of SWQA studies are twofold: (1) to determine the occurrence and, for rivers, seasonal changes in concentrations of a broad list of anthropogenic organic compounds (AOCs) in aquifers and rivers that have some of the largest withdrawals for drinking-water supply (phase 1), and (2) for those AOCs found to occur most frequently in source water, characterize the extent to which these compounds are present in finished water (phase 2). These objectives were met for SWQA studies by collecting ground-water and surfacewater (source) samples and analyzing these samples for 258 AOCs during phase 1. Samples from a subset of wells and surface-water sites located in areas with substantial agricultural production in the watershed were analyzed for 19 additional AOCs, for a total of 277 compounds analyzed for SWQA studies. The 277 compounds were classified according to the following 13 primary use or source groups: (1) disinfection by-products; (2) fumigant-related compounds; (3) fungicides; (4) gasoline hydrocarbons, oxygenates, and oxygenate degradates; (5) herbicides and herbicide degradates; (6) insecticides and insecticide degradates; (7) manufacturing additives; (8) organic synthesis compounds; (9) pavementand combustion-derived compounds; (10) personal care and domestic use products; (11) plant- or animal-derived biochemicals; (12) refrigerants and propellants; and (13) solvents. Source and finished water samples were collected during phase 2 and analyzed for constituents that were detected frequently during phase 1 .

This report presents concentration data for AOCs in ground water, surface water, and finished water of CWSs sampled for SWQA studies during 2002-05. Specifically, this report presents the analytical results of samples collected during phase 1 including (1) samples from 221 wells that were analyzed for 258 AOCs; (2) monthly samples from 9 surfacewater sites that were analyzed for 258 AOCs during phase 1; and (3) samples from a subset of the wells and surface-water sites located in areas with substantial agricultural production that were analyzed for 3 additional pesticides and 16 pesticide degradates. Samples collected during phase 2 were analyzed for selected AOCs that were detected most frequently in source water during phase 1 sampling; analytical results for phase 2 are presented for (1) samples of source water and finished water from 94 wells; and (2) samples of source water and finished water samples that were collected monthly and during selected flow conditions at 8 surface-water sites. Results of quality-assurance/quality-control samples collected for SWQA studies during 2002-05 also are presented.

\section{Introduction}

In 1991, the U.S. Geological Survey (USGS) began the National Water-Quality Assessment (NAWQA) Program to (1) provide a nationally consistent description of current water-quality conditions for the 51 largest and most important aquifers and river basins across the Nation; (2) define longterm trends in water quality; and (3) identify, describe, and explain, as possible, the major factors that affect observed water-quality conditions and trends (Gilliom and others, 1995). This information, which is obtained on a continuing basis, is being made available to water managers, policy 
makers, and the general public to provide an improved scientific basis for evaluating the effectiveness of water-quality management programs and for predicting the likely effects of contemplated changes in land and water-management practices. The first decade of the Program focused on describing current water-quality conditions.

Beginning in 2001, the Program began its second decade of intensive assessment activities, returning to 42 (14 in 2001, 2004, and 2007, respectively) of the 51 original aquifers and river basins studied, termed Study Units. In addition to providing a description of current water-quality conditions, these studies place increased emphasis on the latter two goals of the Program - trends and understanding. In addition, a new assessment activity during the second decade of NAWQA is Source Water-Quality Assessments (SWQAs) that focus on characterizing the quality of source water and finished water of aquifers and major rivers used by some of the larger community water systems (CWSs) in the United States. As used in this study, source water is the raw (ambient) water collected at the supply well prior to water treatment (for ground water) or the raw (ambient) water collected from the river near the intake (for surface water), and finished water is the water that is treated and ready to be delivered to consumers. Finished water is collected before entering the distribution system. Finished water from ground-water supplies may have been blended with water from several ground-water sources, but was not blended with water from any surface-water sources. Finished water from surface-water supplies typically was not blended with any additional surfacewater or ground-water sources.

SWQA studies are intended to complement drinkingwater monitoring required by Federal, State, and local programs, which focus primarily on post-treatment compliance monitoring. Through SWQA studies, NAWQA is increasing its emphasis on characterizing the water quality of rivers and aquifers that are major sources of drinking water and will allow results from other NAWQA sites to be put into context with the source of water used for water supply. Additionally, the quality of source water for a large number of compounds not regulated in drinking water also will be determined. SWQA studies will continue to collaborate with other agencies and organizations involved with supplying and managing drinking water. To help accomplish this, USGS staff maintain a close working relationship with CWS personnel that are utilizing the source waters investigated.

SWQA studies are conducted in two phases, and the objectives of SWQA studies are twofold: (1) to determine the occurrence and, for rivers, seasonal changes in concentrations of a broad list of anthropogenic organic compounds (AOCs) in aquifers and rivers that have some of the largest withdrawals for drinking-water supply (phase 1), and (2) for those AOCs found to occur most frequently in source water, characterize the extent to which these compounds are present in finished water (phase 2). These objectives were met for SWQA studies by collecting ground-water and surface-water (source) samples and analyzing these samples for anthropogenic organic compounds during phase 1 . Source and finished water samples were collected during phase 2 and analyzed for constituents that were detected frequently during phase 1 .

During 2002-05, water-quality was monitored for 15 ground-water SWQAs and 9 surface-water SWQAs. The ground-water and surface-water samples collected during phase 1 were analyzed for 258 AOCs. Samples from a subset of wells and surface-water sites located in areas with substantial agricultural production in the watershed also were analyzed for 3 additional pesticides and 16 pesticide degradates for a total of 277 compounds analyzed for SWQA studies. During phase 2, samples of source water and finished water were collected from a subset of the ground-water and surface-water sites. These samples were analyzed for selected AOCs that were detected most frequently or occurred at relatively higher concentrations during phase 1 sampling.

\section{Purpose and Scope}

The purpose of this report is to present concentration data for AOCs in ground water, surface water, and finished water of CWSs sampled for SWQA studies during 2002-05. No interpretations of the concentration data are included in this report. Specifically, this report presents the analytical results of samples collected during phase 1 including (1) samples from 221 wells that were analyzed for 258 AOCs; (2) monthly samples from 9 surface-water sites that were analyzed for 258 AOCs; and (3) samples from a subset of the wells and surface-water sites located in areas with substantial agricultural production that were analyzed for 3 additional pesticides and 16 pesticide degradates. Samples collected during phase 2 were analyzed for selected AOCs that were detected most frequently in source water during phase 1 sampling; analytical results for phase 2 are presented for (1) samples of source water and finished water from 94 wells; and (2) samples of source water and finished water samples that were collected monthly and during selected flow conditions at 8 surface-water sites. Results of qualityassurance/quality-control samples collected for SWQA studies during 2002-05 also are presented.

\section{Acknowledgments}

The authors thank the many CWS personnel who helped coordinate sample collection and provided permission to sample. Study Unit personnel are thanked for collecting the samples. Jack Barbash, David Bender, and Dana Kolpin are thanked for their help in compiling information for the primary use or source groups for the AOCs. 


\section{Study Design}

This section of the report describes the criteria used for selection of sampling sites during phases 1 and 2 of the SWQA studies. In addition, sample collection, analytical methods, and quality-assurance activities used to characterize the quality of compounds monitored are described.

\section{Selection of Ground-Water Sites}

During 2002-05, water quality from ground-water SWQAs was monitored in 13 NAWQA Study Units with two of these Study Units having two SWQA studies-GeorgiaFlorida Coastal Plain (GAFL) and Upper Mississippi River
Basin (UMIS) - for a total of 15 ground-water SWQAs (fig. 1; table 1). For each ground-water SWQA, about 15 CWS wells were selected for a total of 221 wells sampled during phase 1 .

The selection process for CWS wells considered several criteria. The wells selected withdraw water from a principal aquifer (table 1), or an area representative of an important regional water-supply aquifer (other aquifer), and ground water represents a substantial portion of drinking water in the area. Additionally, ground water used by the selected CWSs was potentially vulnerable to anthropogenic contamination because of large ground-water withdrawal rates from the aquifer and the proximity of wells to urban areas. Finally, the wells sampled fit into a national network of wells that collectively cover a variety of environmental settings such as agriculture, urban, and mixed.

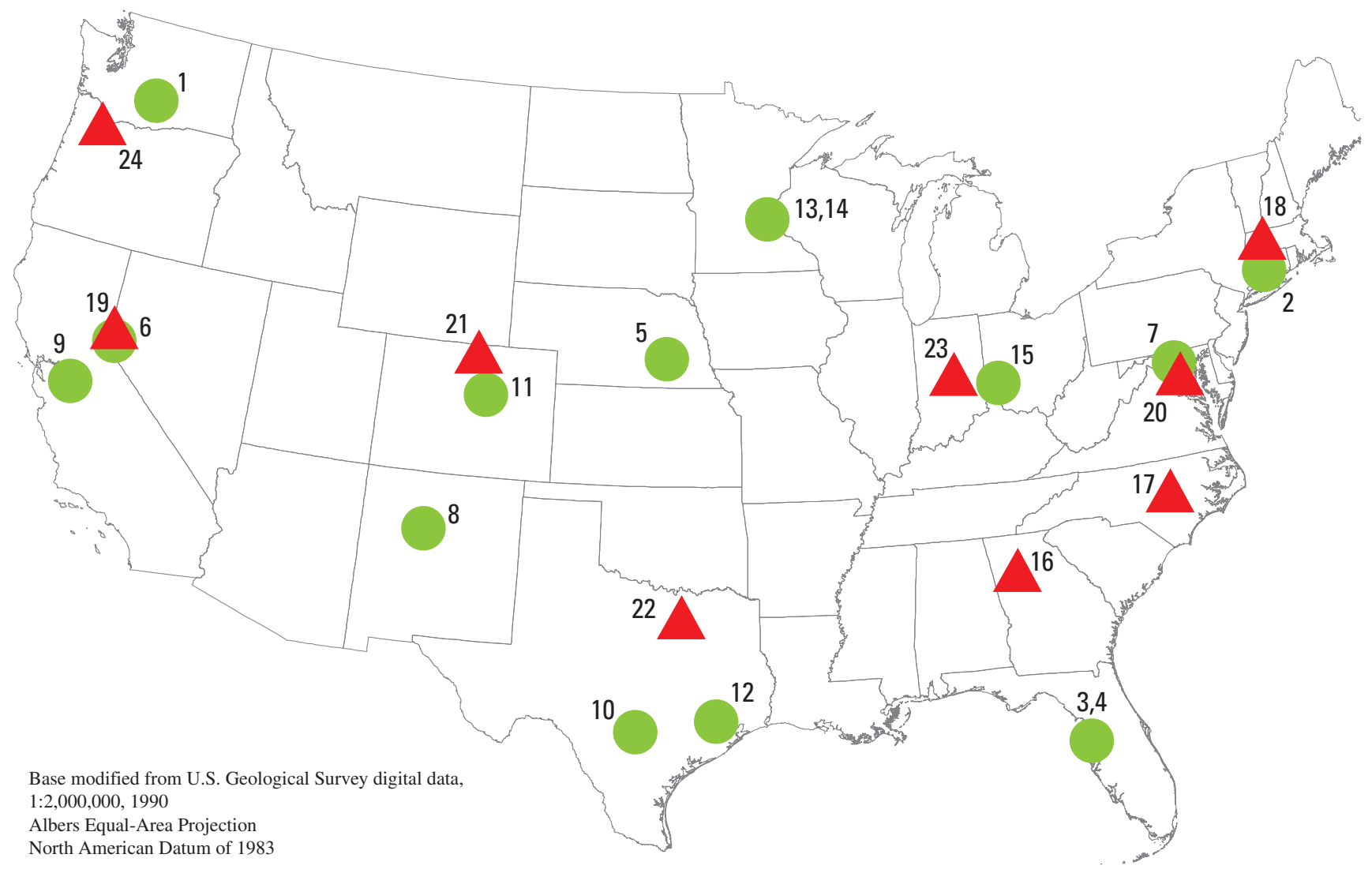

EXPLANATION

Ground water-Number is map number in table 1

Surface water-Number is map number in table 2

Figure 1. Location of Source Water-Quality Assessment studies for which samples were collected during 2002-05. 
Table 1. Principal aquifers sampled for ground-water Source Water-Quality Assessment studies during 2002-05.

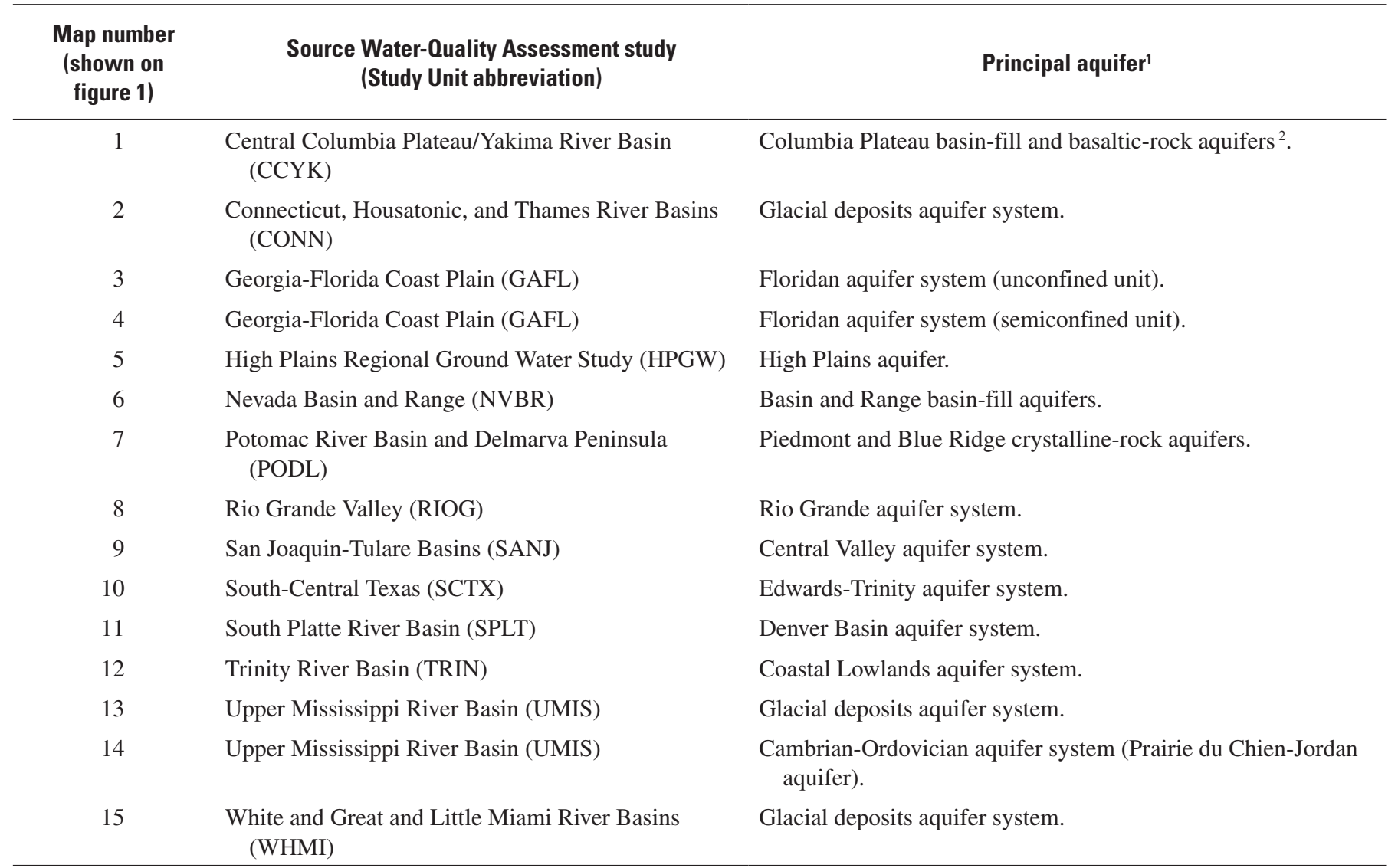

${ }^{1}$ U.S. Geological Survey, 2003.

${ }^{2}$ Principal aquifer consists of a combination of aquifers.

Within an SWQA study area, the highest producing wells typically were selected for sampling because these wells have the largest contributing areas, which may increase the potential for contamination. Annual production data were used to characterize withdrawals for the CWS wells. In some cases, annual production data for individual wells were not available, so production volume for a well field or pumping center was used. The top quartile of individual CWS wells or pumping centers in a study area was characterized, and $15 \mathrm{CWS}$ wells were randomly selected from those in the top quartile. For areas where the top quartile did not contain enough wells or pumping centers for random selection of 15 to occur, a larger group of wells (for example the upper one-half) was used. Wells sampled were at least 1 kilometer apart to ensure that the contributing areas for wells did not overlap.

In certain aquifer systems, some of the highest-producing CWS wells were located near surface-water bodies, which could result in induced infiltration of surface water to the wells. Efforts were made to avoid selection of CWS wells under the influence of surface water. Similarly, CWS wells in coastal or bay areas with induced infiltration from seawater, and wells used for injection and subsequent withdrawal of artificial recharge also were avoided because water from these types of wells does not represent recharge from the land surface.

Phase 1 sampling activities monitored AOC concentrations in the source water of about 15 CWS wells per SWQA study for a total of 221 CWS wells. Phase 2 sampling was a focused activity that monitored concentrations in samples from a subset of the phase 1 wells for those AOCs found to occur most frequently or at relatively higher concentrations during phase 1 . During phase 2, source water and finished water were monitored for 94 of the $221 \mathrm{CWS}$ wells sampled during phase 1 . Finished water from 57 of the 94 sites sampled during phase 2 were blended with water from other ground-water wells prior to distribution and sampling, and water from 37 were not blended. Only one set of sourcewater samples was collected from the Rio Grande Valley (RIOG) SWQA study; thus, phase 1 and phase 2 samples for this study are the same. 


\section{Selection of Surface-Water Sites}

During 2002-05, water quality from surface-water SWQAs was monitored in nine NAWQA Study Units (fig. 1; table 2). During phase 1, one site was selected for each SWQA and sampled monthly for about 1 year. During phase 2, source water and finished water were sampled for eight of the surface-water SWQAs.

Several criteria were used in selecting a surface-water CWS site for SWQA monitoring. Source-water sites were selected on free-flowing stream reaches rather than on reservoirs to remain consistent with and to be able to compare results with other surface-water sites sampled by the NAWQA Program. In some cases, reservoirs were upstream from the surface-water CWS sites, but the closest reservoir is about 12 river miles upstream from the CWS intake. Additionally, CWSs selected for this study were single-source systems, with little or no blending of other source waters. Land use in the watershed and the type of water treatment used by the CWSs were not considerations in site selection.

The SWQA surface-water sites represent a range in size (table 2) and are fairly well distributed across the United States (fig. 1). Eight of the nine CWSs are categorized as large or very large water systems, meaning that they provide water to more than 10,001 and 100,001 people, respectively (U.S. Environmental Protection Agency, 2006a). One site, Running Gutter Creek, Massachusetts, is a small CWS that serves fewer than 3,300 people.

Table 2. Rivers sampled for surface-water Source Water-Quality Assessment studies during 2002-05.

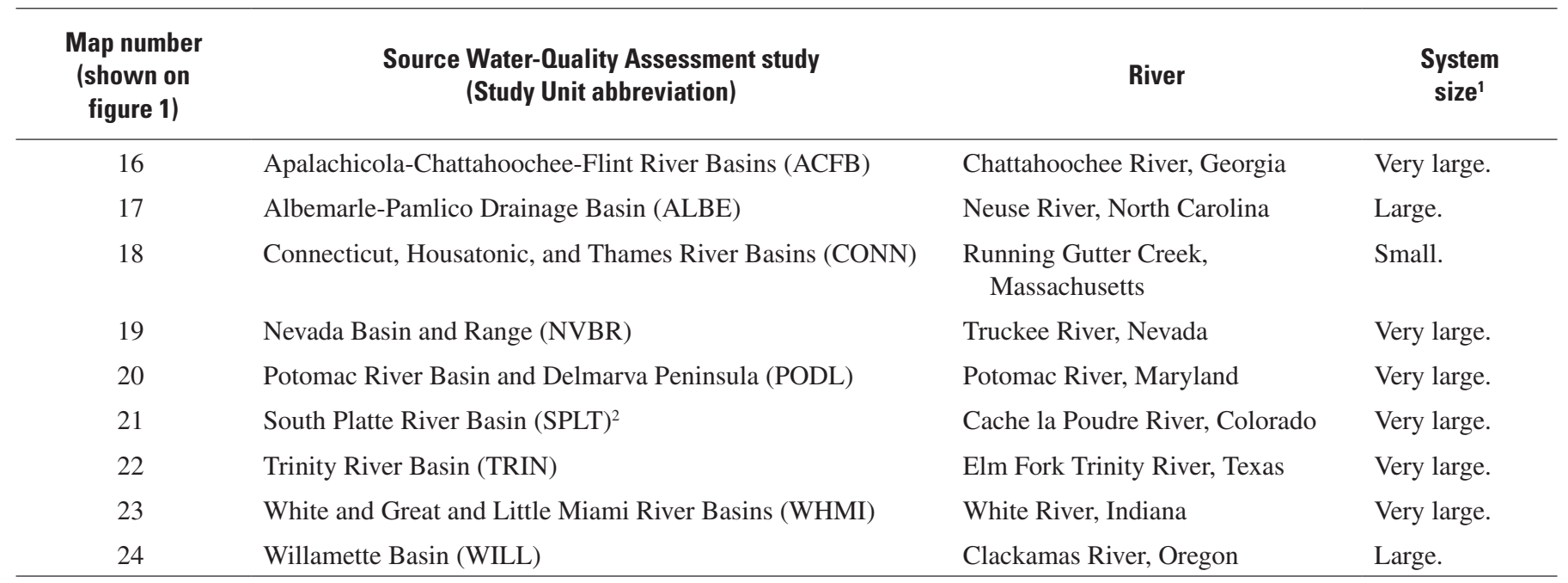

${ }^{1}$ System size is defined by U.S. Environmental Protection Agency (2006a) as follows: small, serving fewer than 3,300 people; large, serving between 10,001 and 100,001 people; and very large, serving more than 100,001 people.

${ }^{2}$ No source-water or finished-water samples from this site were collected during phase 2.

\section{Compounds Monitored}

The 277 AOCs analyzed for SWQA studies were categorized into the following 13 compound groups on the basis of their primary use or source (table 3): (1) disinfection by-products; (2) fumigant-related compounds; (3) fungicides; (4) gasoline hydrocarbons, oxygenates, and oxygenate degradates, (5) herbicides and herbicide degradates;
(6) insecticides and insecticide degradates; (7) manufacturing additives; (8) organic synthesis compounds; (9) pavementand combustion-derived compounds; (10) personal care and domestic use products; (11) plant- or animal-derived biochemicals; (12) refrigerants and propellants; and (13) solvents. Selected information for the compounds analyzed for SWQA studies is presented in Appendix 1. 
Table 3. Primary use or source groups for compounds analyzed for ground-water and surface-water Source Water-Quality Assessment studies.

[BTEX: benzene, toluene, ethylbenzene, and xylenes]

\begin{tabular}{|c|c|c|}
\hline Primary use or source group & Description & $\begin{array}{l}\text { Number of } \\
\text { compounds in } \\
\text { group }\end{array}$ \\
\hline Fungicides & Pesticides that are used to kill unwanted fungi. & 7 \\
\hline $\begin{array}{l}\text { Gasoline hydrocarbons, } \\
\text { oxygenates, and oxygenate } \\
\text { degradates }\end{array}$ & $\begin{array}{l}\text { Gasoline hydrocarbons are straight, branched, and (or) cyclic organic compounds that are } \\
\text { highly volatile, contain only carbon and hydrogen atoms, and are common ingredients } \\
\text { in gasoline and other petroleum products. Among these compounds, BTEX compounds } \\
\text { are among those present in the highest proportions in gasoline. Oxygenates, such as } \\
\text { methyl tert-butyl ether (MTBE), are compounds that contain only carbon, hydrogen, } \\
\text { and oxygen atoms and are commonly added to gasoline to improve the efficiency of } \\
\text { combustion. Oxygenate degradates are formed during the production, storage, release, } \\
\text { and (or) use of gasoline oxygenates or following their release into the environment. }\end{array}$ & 27 \\
\hline $\begin{array}{l}\text { Herbicides and herbicide } \\
\text { degradates }\end{array}$ & $\begin{array}{l}\text { Pesticides designed to kill unwanted plants (herbicides) and compounds produced from } \\
\text { the transformation of the parent herbicide following application (degradates). }\end{array}$ & 82 \\
\hline $\begin{array}{l}\text { Insecticides and insecticide } \\
\text { degradates }\end{array}$ & $\begin{array}{l}\text { Pesticides designed to kill unwanted insects (insecticides) and compounds produced from } \\
\text { the transformation of the parent insecticide following application (degradates). }\end{array}$ & 51 \\
\hline Manufacturing additives & $\begin{array}{l}\text { Compounds used in commercial formulations of chemical products in order to improve } \\
\text { the effectiveness of the product, including plasticizers (to increase the flexibility of } \\
\text { plastics), fire retardants, corrosion inhibitors, and pesticide adjuvants. }\end{array}$ & 7 \\
\hline $\begin{array}{l}\text { Personal care and domestic } \\
\text { use products }\end{array}$ & $\begin{array}{l}\text { Compounds that are present in commercial products sold for personal or residential use, } \\
\text { such as fragrances, pharmaceuticals, insect repellents, dyes, detergents, disinfectants, } \\
\text { shampoos, and chemicals used in fire extinguishers. }\end{array}$ & 26 \\
\hline $\begin{array}{l}\text { Plant- or animal-derived } \\
\text { biochemicals }\end{array}$ & $\begin{array}{l}\text { Naturally occurring compounds that are produced by plants or animals, either through } \\
\text { direct biosynthesis or through the metabolic alteration of compounds ingested or taken } \\
\text { up from other sources. These compounds are predominantly unsaturated solid alcohols } \\
\text { of the steroid group naturally occurring in fatty tissues of plants and animals and present } \\
\text { in animal fecal material. }\end{array}$ & 5 \\
\hline Refrigerants and propellants & $\begin{array}{l}\text { Volatile compounds that are used for commercial or domestic refrigeration, as blowing } \\
\text { agents in the manufacture of packaging and other highly porous materials, or for } \\
\text { dispensing other substances from spray cans and other aerosol delivery devices. }\end{array}$ & 3 \\
\hline Solvents & $\begin{array}{l}\text { Compounds that are used to dissolve other substances. Two of the more common solvents } \\
\text { are trichloroethene (TCE) and tetrachloroethene (perchloroethene, PCE). }\end{array}$ & 33 \\
\hline Total number of compounds & & 277 \\
\hline
\end{tabular}




\section{Sample Collection and Analytical Methods}

Ground-water, surface-water, and quality-control samples were collected using established USGS protocols (Koterba and others, 1995; U.S. Geological Survey, 1997-2006). Groundwater samples were collected at the wellhead before any treatment such as chlorination. Surface-water samples were collected monthly with additional samples collected during selected flow conditions when water quality may change quickly or when large concentrations were likely to occur. These samples were collected at a single depth integrated point as close as practical to the drinking-water intake and processed following standard USGS sampling protocols (U.S. Geological Survey, 1997-2006).

During phase 2, a finished-water sample that corresponded to each ground-water and surface-water sourcewater sample was collected following all of the treatment steps prior to the water entering the water treatment plants' distribution systems. These samples typically were collected where samples are collected for compliance monitoring. The finished-water samples were collected several hours or as much as 2 days after the source-water samples to try to account for the residence time in the treatment plants. Finished-water samples typically contain free chlorine, which has been documented to degrade certain organic compounds that may be present in the water samples (Munch, 1995). Therefore, a dechlorination reagent (ascorbic acid) and, for certain samples, $\mathrm{pH}$ buffers (Trizma) were added to finishedwater samples during sample collection to stabilize them prior to analyses. The effect of these dechlorination reagents on the laboratory analysis was evaluated, and results indicated that analytical methodologies were not affected by the addition of these reagents (Mark Sandstrom, U.S. Geological Survey National Water Quality Laboratory, written commun., 2007). Finished-water sample results are not necessarily representative of drinking-water quality at the tap because samples were collected prior to distribution and thus do not account for the additional contact time water has with disinfectants in the distribution system.

Samples were analyzed using five USGS approved analytical methods at the USGS National Water Quality Laboratory (NWQL) in Denver, Colorado, and described by Zaugg and others (1995), Lindley and others (1996), Connor and others (1998), Furlong and others (2001), Sandstrom and others (2001), Zaugg and others (2002), and Madsen and others (2003). These methods include both gas chromatography-mass spectrometry (GC/MS) and high performance liquid chromatography-mass spectrometry (HPLC/MS) analytical techniques. Samples collected for volatile organic compound (VOC) analyses using schedules 2020 and 4024 (Appendix 1) were chilled upon collection. Samples collected for analyses using schedule 2020 also were preserved using 1:1 hydrochloric acid. VOC sample sets were analyzed by purge and trap GC/MS (Connor and others, 1998; Rose and Sandstrom, 2003). Samples for analyses of pesticides and other semi-volatile compounds were filtered in the field through a 0.7-micron baked glass fiber filter and chilled. These samples were extracted at the NWQL on solid phase extraction (SPE) cartridges to concentrate the analytes from the filtered samples. SPE cartridges were then eluted with a solvent and the extracts were analyzed by either GC/MS or HPLC/MS methods (Zaugg and others, 1995; Lindley and others, 1996; Furlong and others, 2001; Sandstrom and others, 2001; Zaugg and others, 2002; Madsen and others, 2003). At a subset of sites, an additional sample was collected for the analysis of 3 herbicides and 16 herbicide degradates. These additional samples were analyzed using HPLC/MS by the Organic Geochemistry Research Group Laboratory, in Lawrence, Kansas (Lee and Strahan, 2003).

AOC concentrations detected below the lowest daily standard, and/or for information-rich methods, concentrations detected below the long-term method detection level (LT-MDL), are reported as estimated concentrations (Childress and others, 1999). The laboratory report level (LRL) generally is equal to twice the yearly determined LT-MDL (Childress and others, 1999). The LT-MDL is a detection level derived by determining the standard deviation or a minimum of $24 \mathrm{MDL}$ spike-sample measurements over an extended time. LT-MDL data are collected on a continuous basis to assess year-to-year variations in the LT-MDL. The chance of falsely reporting a concentration at or greater than the LT-MDL for a sample that did not contain the analyte is predicted to be less than or equal to 1 percent (Childress and others, 1999). Also, at low concentrations, especially concentrations less than the LRL, the variability of detection is high, false negatives are more likely, and greater variability in reported concentrations is expected (Martin, 2002). Concentrations greater than the LRL sometimes are reported as estimated concentrations for some AOCs because of the variability in the analytical method, poor recovery, or by loss processes such as water-matrix interferences that result in false-negative errors. Concentrations are censored and reported as less than $(<)$ the LRL when the compound was not detected.

\section{Quality Assurance}

Quality-assurance/quality-control samples collected for SWQA studies include equipment blanks, field blanks, source solution blanks, and replicate samples. Equipment blanks evaluate the cleanliness of sampling equipment and typically are collected before the environmental sample is collected. Field blanks are collected near sampling sites and evaluate potential sample contamination from sampling equipment, cleaning procedures, and the atmosphere. Source solution blanks are used to determine the presence or absence of compounds in the water used to clean equipment and process field blanks. The various blank samples also provide information on contamination and (or) concentration loss during shipment. Replicate samples measure the combined precision of sampling and laboratory analyses. 
Data from all source-water, finished-water, and qualitycontrol (QC) samples collected by each SWQA study area were reviewed to evaluate potential bias (primarily systematic contamination) and variability associated with sample collection, processing, transportation, and analysis. A review of the QC data along with the associated environmental data is important because the relatively small number of samples collected in each study area generally is not adequate to characterize the full magnitude of potential bias on an individual SWQA basis. A larger data set that covers the entire period of sample collection for SWQA studies provides greater insight to possible systematic errors that bias sample results. These $\mathrm{QC}$ reviews were completed on an annual basis. If QC data indicated that results for environmental data were biased as a result of systematic contamination, environmental data were removed from the data set.

Phenol was detected frequently in both field and laboratory blanks and at concentrations comparable to concentrations measured in environmental samples. Phenol was removed from the data set, and no phenol concentrations are included in this report. Studies conducted by the NWQL (Mark Sandstrom, USGS National Water Quality Laboratory, oral commun., 2005) indicated that samples can be contaminated if N,N-diethyl-meta-toluamide (DEET) is used by sampling personnel. The frequent detection of DEET in field blanks caused uncertainty in the quality of DEET concentrations in environmental samples; thus, concentrations for DEET were removed for this report by coding concentrations with an "R." Three compoundsbenzophenone, isophorone, and para-nonylphenol—were detected frequently in field blanks due to the presence of these compounds in the $\mathrm{pH}$ buffer (Trizma) obtained from the vendor. Because the quality of data for benzophenone, isophorone, and para-nonylphenol is not fully understood, concentrations for these three compounds also were removed for this report by coding concentrations with an "R."

For compounds detected in 50 percent or more of an individual Study Unit's field blank samples, all environmental and quality-control data for that Study Unit were removed for this report by coding concentrations with an "R." After these concentrations were removed, compounds detected in 5 percent or more of all field blank samples were evaluated, and all detections of those compounds in environmental samples that were less than or equal to the highest blank concentration were censored by coding environmental concentrations with a " $\mathrm{C}<$ " in the remark columns and by changing the concentration to the highest blank concentration.

\section{Concentration Data}

Concentration data for the AOCs are presented in Appendix 2 for the ground-water SWQAs and in Appendix 3 for the surface-water SWQAs. The quality-assurance/ quality-control data associated with the ground-water and surface-water SWQAs also are presented in Appendixes 2 and 3, respectively. The concentration data are presented in two formats: (1) Microsoft Excel spreadsheets, and (2) tabdelimited text files. The concentration data are presented by the primary use or source groups as defined in table 3 . Concentrations for each of the 13 groups are presented either as a separate worksheet within the Excel spreadsheets, or as individual files for the tab-delimited text files.

Data are presented within each worksheet or text file in a similar order. First, the source-water (ground-water or surfacewater) and finished-water samples are presented (sample type: regular), followed by quality-assurance/quality-control samples (sample types: equipment blanks, field blanks, source solution blanks, replicates, and spikes). The sample medium indicates whether the regular sample was of ground water (source water), surface water (source water), or finished water and whether the quality-assurance/quality-control samples were associated with ground water (source water), surface water (source water), or finished water.

The concentrations presented in Appendixes 2 and 3 are not rounded; concentrations are presented as received from the laboratories, with the following exceptions: (1) concentrations for benzophenone, isophorone, DEET, and para-nonylphenol (total) were removed by coding concentrations with an "R" in the remark columns; (2) concentrations for phenol are not included; (3) for compounds detected in 50 percent or more of an individual Study Unit's field blank samples, all environmental and quality-control data for that Study Unit were removed for this report by coding concentrations with an "R;" and after removal of those data, (4) compounds detected in 5 percent or more of all field blank samples were evaluated, and all detections of those compounds in environmental samples that were less than or equal to the highest blank concentration were censored by coding environmental concentrations with a " $\mathrm{C}<$ " in the remark columns and by changing the concentration to the highest blank concentration. The remark columns indicate whether a concentration was too low to be quantified (reported as a less than $(<)$ value), censored (C), estimated (E), or removed (R). 


\section{References Cited}

Agency for Toxic Substances and Disease Registry (ATSDR), 1992a, Toxicological profile for 1,2,3-trichloropropane, accessed January 17, 2007, at $h t t p: / / w w w . a t s d r . c d c . g o v /$ toxprofiles/tp57.html

Agency for Toxic Substances and Disease Registry (ATSDR), 1992b, Toxicological profile for 2-hexanone, accessed February 16, 2007, at $h t t p: / / w w w . a t s d r . c d c . g o v / t o x p r o f i l e s /$ tp44.html

Barbash, J.E., and Reinhard, M., 1989, Abiotic dehalogenation of 1,2-dichloroethane and 1,2-dibromoethane in aqueous solution containing hydrogen sulphide: Environmental Science and Technology, v. 23, no. 11, p. 1,349-1,358.

Bender, D.A., Zogorski, J.S., Halde, M.J., and Rowe, B.L., 1999, Selection procedure and salient information for volatile organic compounds emphasized in the National Water-Quality Assessment Program: U.S. Geological Survey Open-File Report 99-182, 32 p.

Bradley, P.M., Chapelle, F.H., and Landmeyer, J.E., 2001, Effect of redox conditions on MTBE biodegradation in surface water sediments: Environmental Science and Technology, v. 35 , no. 23 , p. 4,643-4,647.

Budavari, Susan, ed., 1989, The Merck Index (11th ed.): Rahway, N.J., Merck and Company, Inc. [variously paged].

Budavari, Susan, ed., 1996, The Merck Index (12th ed.): Whitehouse Station, N.J., Merck and Company, Inc. [variously paged].

California Environmental Protection Agency, 1999, Final prioritized candidate chemicals under consideration for carcinogenicity evaluation-Fifty-four chemicals within batch \#3, accessed January 17, 2007, at http://www.oehha. ca.gov/prop65/pdfffbatch3.pdf

CambridgeSoft Corporation, 2004, Chemfinder, accessed January 17, 2007, at http://chemfinder.cambridgesoft.com/ result.asp

Chemicalland21, 2007, Tolutraizole, accessed January 17, 2007, at http://www.chemicalland21.com/specialtychem/ finechem/TOLUTRIAZOLE.htm

Childress, C.J.O., Foreman, W.T., Connor, B.F., and Maloney, T.J., 1999, New reporting procedures based on longterm method detection levels and some considerations for interpretations of water-quality data provided by the U.S. Geological Survey National Water Quality Laboratory: U.S. Geological Survey Open-File Report 99-193, 19 p.
Cohen, D.B., Gilmore, D., Fischer, C., Bowes, G., 1983, Water quality and pesticides-1,2-Dichloropropane (1,2-D) and 1,3-dichloropropene (1,3-D): Sacramento, Calif., California State Water Resources Control Board, Water Quality and Pesticides Special Projects Report No. 83-8SP.

Connor, B.F., Rose, D.L., Noriega, M.C., Murtagh, L.K., and Abney, S.R., 1998, Methods of analysis by the U.S. Geological Survey National Water Quality Laboratory-Determination of 86 volatile organic compounds in water by gas chromatography/mass spectrometry, including detections less than reporting limits: U.S. Geological Survey Open-File Report 97-829, 78 p.

Cozzarelli, I.M., Baedecker, M.J., Eganhouse, R.P., and Goerlitz, D.F., 1994, The geochemical evolution of low-molecular-weight organic acids derived from the degradation of petroleum contaminants in groundwater: Geochimica et Cosmochimica Acta, v. 58, no. 2, p. $863-877$.

Cozzarelli, I.M., Eganhouse, R.P., and Baedecker, M.J., 1990, Transformation of monoaromatic hydrocarbons to organic acids in anoxic groundwater environment: Environmental Geology, v. 16, no. 2, p. 135-141.

Egli, Christine; Tschan, Thomas; Scholtz, Rudolf; Cook, A.M.; Leisinger, Thomas, 1988, Transformation of tetrachloromethane to dichloromethane and carbon dioxide by acetobacterium woodii: Applied and Environmental Microbiology, v. 54, no. 11, p. 2,819-2,824.

Furlong, E.T., Anderson, B.D., Werner, S.L., Soliven, P.P., Coffey, L.J., and Burkhardt, M.R., 2001, Methods of analysis by the U.S. Geological Survey National Water Quality Laboratory-Determination of pesticides in water by graphitized carbon-based solid-phase extraction and high-performance liquid chromatography/mass spectrometry: U.S. Geological Survey Water-Resources Investigations Report 01-4134, $73 \mathrm{p}$.

Gilliom, R.J., Alley, W.M., and Gurtz, M.E., 1995, Design of the National Water-Quality Assessment ProgramOccurrence and distribution of water-quality conditions: U.S. Geological Survey Circular 1112, 33 p.

Glassmeyer, S.T., Furlong, E.T., Kolpin, D.W., Cahill, J.D., Zaugg, S.D., Werner, S.L., Meyer, M.T., Kryak, D.D., 2005, Transport of chemical and microbial compounds from known wastewater discharges - Potential for use as indicators of human fecal contamination: Environmental Science and Technology, v. 39, p. 5,157-5,169.

Haag, W.R., and Mill, T., 1988, Effect of a subsurface sediment on hydrolysis of haloalkanes and epoxides: Environmental Science and Technology, v. 22, no. 6, p. 658-663. 
Hladik, M.L., Hsiao, J.J., and Roberts, A.L., 2005, Are neutral chloroacetamide herbicide degradates of potential environmental concern? Analysis and occurrence in the Upper Chesapeake Bay: Environmental Science and Technology, v. 39, no. 17, p. 6,561-6,574.

Klecka, G.M., Gonsoir, S.J., and Markham, D.A., 1990, Biological transformations of 1,1,1-trichloroethane in subsurface soils and ground water: Environmental Toxicology and Chemistry, v. 9, no. 12, p. 1,437-1,451.

Kolpin, D.W., Furlong, E.T., Meyer, M.T., Thurman, E.M., Zaugg, S.D., Barber, L.B., and Buxton, H.T., 2002, Pharmaceuticals, hormones, and other organic wastewater contaminants in U.S. streams, 1999-2000-A national reconnaissance: Environmental Science and Technology, v. 36 , no. 6 , p. 1,202-1,211.

Koterba, M.T., Wilde, F.D., and Lapham, W.W., 1995, Ground-water data-collection protocols and procedures for the National Water-Quality Assessment ProgramCollection and documentation of water-quality samples and related data: U.S. Geological Survey Open-File Report 95-399, $113 \mathrm{p}$.

Lee, E.A., and Strahan, A.P., 2003, Methods of analysis by the U.S. Geological Survey Organic Geochemistry Research Group-Determination of acetamide herbicides and their degradation products in water using online solid-phase extraction and liquid chromatography/mass spectrometry: U.S. Geological Survey Open-File Report 03-173, 17 p.

Lindley, C.E., Stewart, J.T., and Sandstrom, M.W., 1996, Determination of low concentrations of acetochlor in water by automated solid-phase extraction and gas chromatography with mass selective detection: Journal of Association of Official Analytical Chemists International, v. 79, no. 4, p. 962-966.

Lorah, M.M., and Olsen, L.D., 1999, Natural attenuation of chlorinated volatile organic compounds in a freshwater tidal wetland-Field evidence of anaerobic biodegradation: Water Resources Research, v. 35, no. 12, p. 3,811-3,828.

Madsen, J.F., Sandstrom, M.W., and Zaugg, S.D., 2003, Methods of analysis by the U.S. Geological Survey National Water Quality Laboratory-A method supplement for the determination of fipronil and degradates in water by gas chromatography/mass spectrometry: U.S. Geological Survey Open-File Report 02-462, 11 p.

Martin, J.D., 2002, Variability of pesticide detections and concentrations in field replicate water samples collected for the National Water-Quality Assessment Program, 1992-97: U.S. Geological Survey Water-Resources Investigations Report 01-4178, 84 p.
Megonigal, J.P., Hines, M.E., and Visscher, P.T., 2004, Anaerobic metabolism-Linkages to trace gases and aerobic processes, in Schlesinger, W.H., ed., Biogeochemistry: Oxford, United Kingdom, ElsevierPergamon, p. 317-424, accessed January 17, 2007, at http:// www.serc.si.edu/labs/biogeochem/publications/Megonigal_ Hines_Visscher_2004_V2.pdf

Munch, J.W., 1995, Method 524.2.-Measurement of purgeable organic compounds in water by capillary column gas chromatography/mass spectrometry, revision 4.1: Cincinnati, Ohio, Environmental Monitoring Systems Laboratory, U.S. Environmental Protection Agency, 48 p.

National Oceanic and Atmospheric Administration, 2005, Air Resources Laboratory, accessed December 22, 2006, at http://www.arl.noaa.gov/faq/ac4.html

Pankow, J.F., Rathbun, R.E., and Zogorski, J.S., 1996, Calculated volatilization rates of fuel oxygenate compounds and other gasoline-related compounds from rivers and streams: Chemosphere, v. 33, no. 5, p. 921-937.

Rose, D.L., and Sandstrom, M.W., 2003, Methods of analysis by the U.S. Geological Survey National Water Quality Laboratory-Determination of gasoline oxygenates, selected degradates, and BTEX in water by heated purge and trap/gas chromatography/mass spectrometry: U.S. Geological Survey Water-Resources Investigations Report 03-4079, 31 p.

Sandstrom, M.W., Stroppel, M.E., Foreman, W.T., and Schroeder, M.P., 2001, Methods of analysis by the U.S. Geological Survey National Water Quality Laboratory-Determination of moderate-use pesticides and selected degradates in water by $\mathrm{C}-18$ solid-phase extraction and gas chromatography/mass spectrometry: U.S. Geological Survey Water-Resources Investigations Report 01-4098, 70 p.

Scorecard, 2006, Chemical profiles, accessed December 22, 2006, at http://www.scorecard.org/chemical-profiles/ index.tcl

Spectrum Laboratories Inc., 2007, Chemical fact sheet, accessed January 17, 2007, at http://www.speclab.com/ compound/c591786.htm

Tesoriero, A.J., Loffler, F.E., and Liebscher, Hugh, 2001, Fate and origin of 1,2-dichloropropane in an unconfined shallow aquifer: Environmental Science and Technology, v. 35, no. 3, p. 455-461.

United Nations Environmental Programme, 2002, Methyl acrylonitrile, accessed January 17, 2007, at http://www. chem.unep.ch/irptc/sids/OECDSIDS/126987.pdf 
U.S. Environmental Protection Agency, 2006a, Public drinking water systems-Facts and figures, accessed December 22, 2006, at http://www.epa.gov/safewater/pws/factoids.html

U.S. Environmental Protection Agency, 2006b, Inert (other) pesticide ingredients in pesticide products - Categorized list of inert (other) pesticide ingredients, accessed January 16, 2007, at http://www.epa.gov/opprd001/inerts/lists.html

U.S. Environmental Protection Agency, 2006c, Iodomethane risk assessment; notice of availability, accessed January 17 , 2007, at http://www.epa.gov/fedrgstr/EPA-PEST/2006/ January/Day-06/p28.htm

U.S. Geological Survey, 1997-2006, National field manual for the collection of water-quality data: U.S. Geological Survey Techniques of Water-Resources Investigations, book 9, chaps. A1-A9, available at http://pubs.water.usgs. gov/twri9A (chapters were originally published during 1997-1999; updates and revisions are ongoing and are summarized at http://water.usgs.gov/owq/FieldManual/ mastererrata.html).

U.S. Geological Survey, 2003, Principal aquifers of the 48 conterminous United States, Hawaii, Puerto Rico, and the U.S. Virgin Islands, accessed March 1, 2007, at http://www. nationalatlas.gov/mld/aquifrp.html

U.S. Geological Survey, 2007, Toxic Substances Hydrology Program-Fuel oxygenates, accessed January 17, 2007, at http://toxics.usgs.gov/definitions/fuel_oxygenates.html

U.S. National Library of Medicine, 2004, Household products database, accessed January 17, 2007, at http://householdproducts.nlm.nih.gov/

U.S. National Library of Medicine, 2006, TOXNETToxicology data network, accessed December 22, 2006, at http://toxnet.nlm.nih.gov/
Vogel, T.M., and McCarty, P.L., 1985, Biotransformation of tetrachloroethylene to trichloroethylene, dichloroethylene, vinyl chloride, and carbon dioxide under methanogenic conditions: Applied and Environmental Microbiology, v. 49, no. 5 , p. $1,080-1,083$.

Wiedemeier, T.H., Swanson, M.A., Wilson, J.T., Kampbell, D.H., Miller, R.H., and Hansen, J.E., 1996, Approximation of biodegradation rate constants for monoaromatic hydrocarbons (BTEX) in ground water: Ground Water Monitoring and Remediation, v.16, no. 3, p. 186-194.

Wood, Alan, 2006, Compendium of pesticide common names, accessed December 22, 2006, at http://www.alanwood. net/pesticides/index_cn_frame.html

Zaugg, S.D., Sandstrom, M.W., Smith, S.G., and Fehlberg, K.M., 1995, Methods of analysis by the U.S. Geological Survey National Water Quality Laboratory-Determination of pesticides in water by $\mathrm{C}-18$ solid-phase extraction and capillary-column gas chromatography/mass spectrometry with selected-ion monitoring: U.S. Geological Survey Open-File Report 95-181, 49 p.

Zaugg, S.D., Smith, S.G., Schroeder, M.P., Barber, L.B., and Burkhardt, M.R., 2002, Methods of analysis by the U.S. Geological Survey National Water Quality Laboratory-Determination of wastewater compounds by polystyrene-divinylbenzene solid-phase extraction and capillary-column gas chromatography/mass spectrometry: U.S. Geological Survey Water-Resources Investigations Report 01-4186, 37 p.

Zogorski, J.S., Carter, J.M., Ivahnenko, Tamara, Lapham, W.W., Moran, M.J., Rowe, B.L., Squillace, P.J., and Toccalino, P.L, 2006, The quality of our Nation's watersVolatile organic compounds in the Nation's ground water and drinking-water supply wells: U.S. Geological Survey Circular 1292, 101 p. 
This page intentionally left blank. 
Appendix 1. Compounds analyzed in Source Water-Quality Assessment studies by primary use or source groups. 


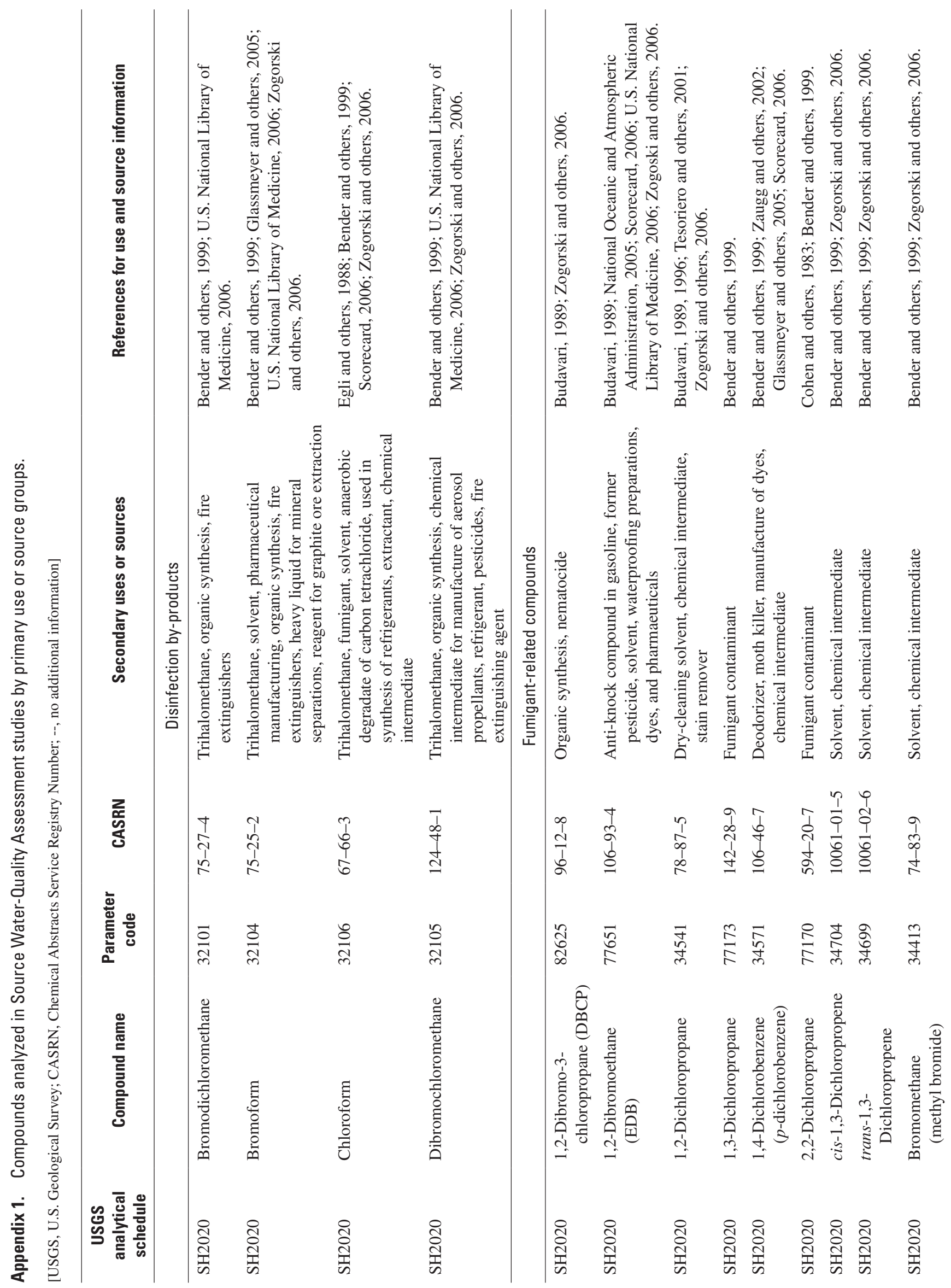




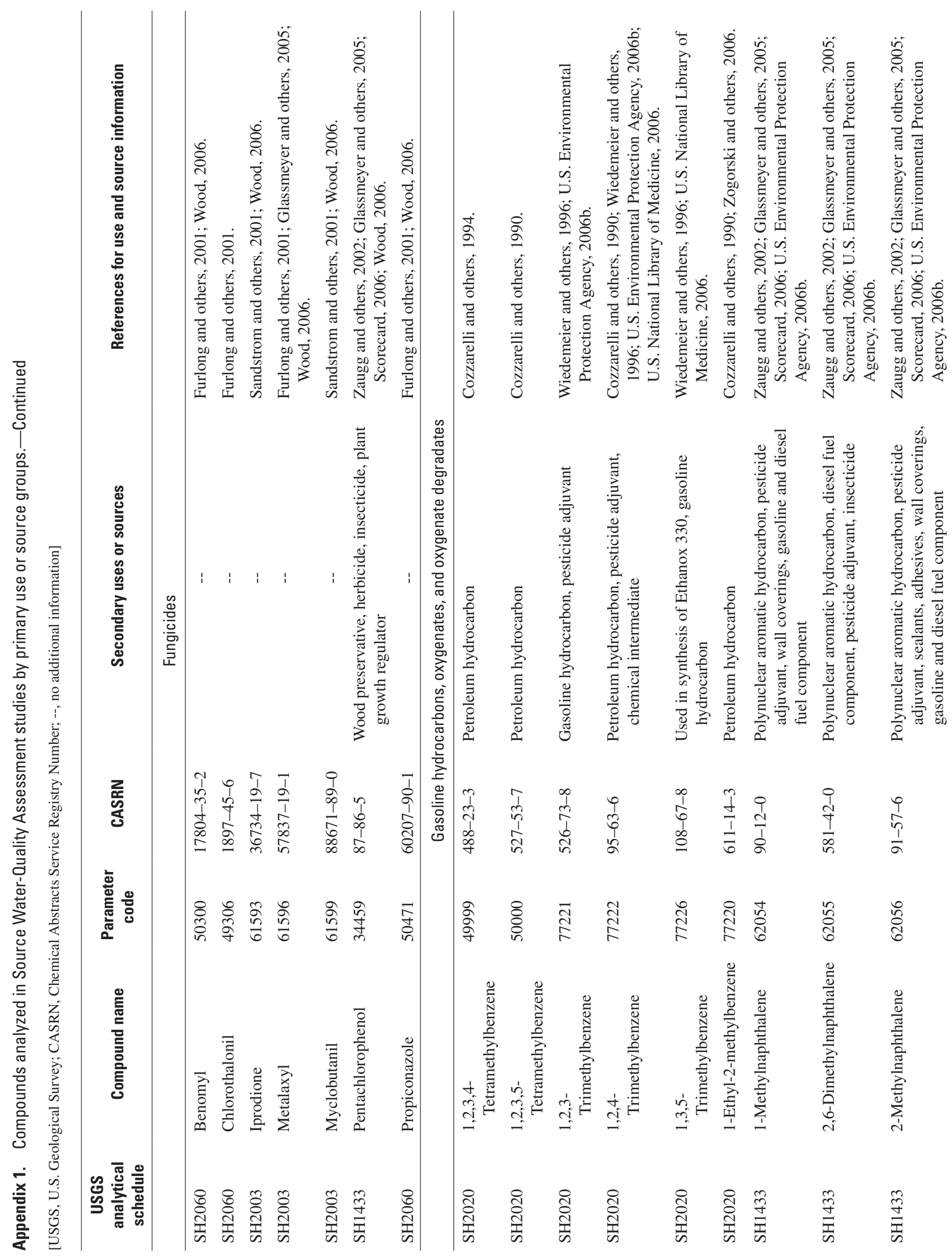




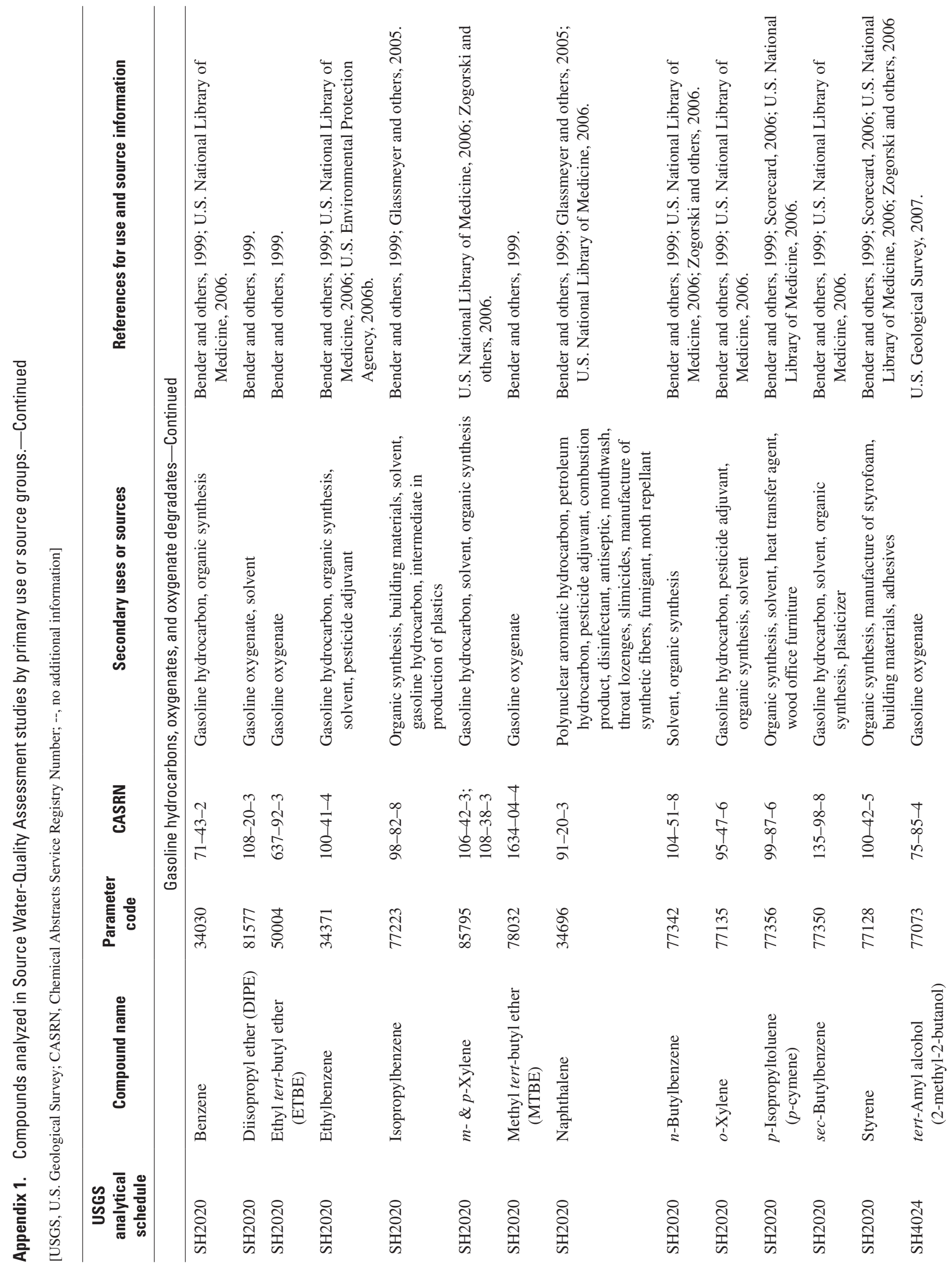




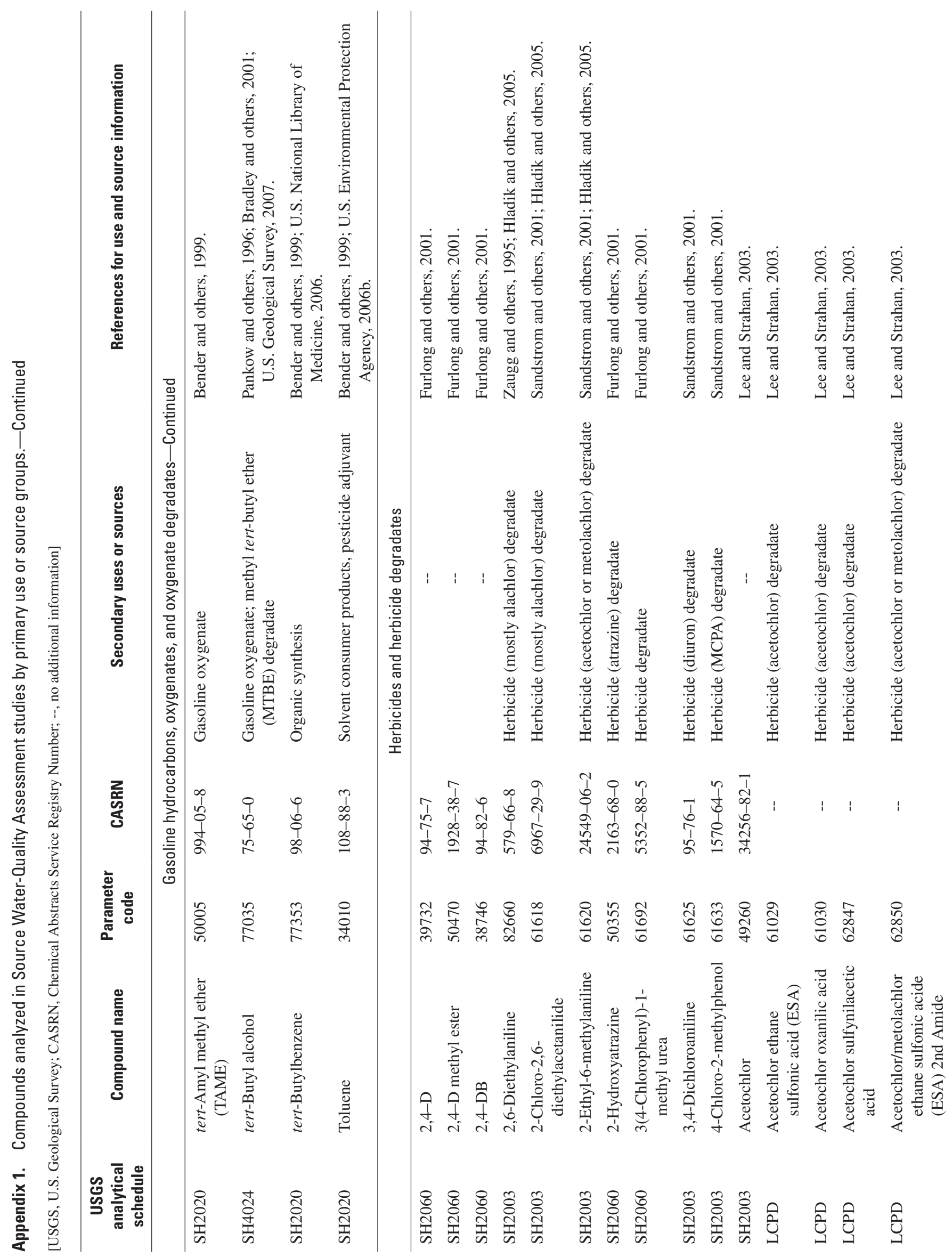




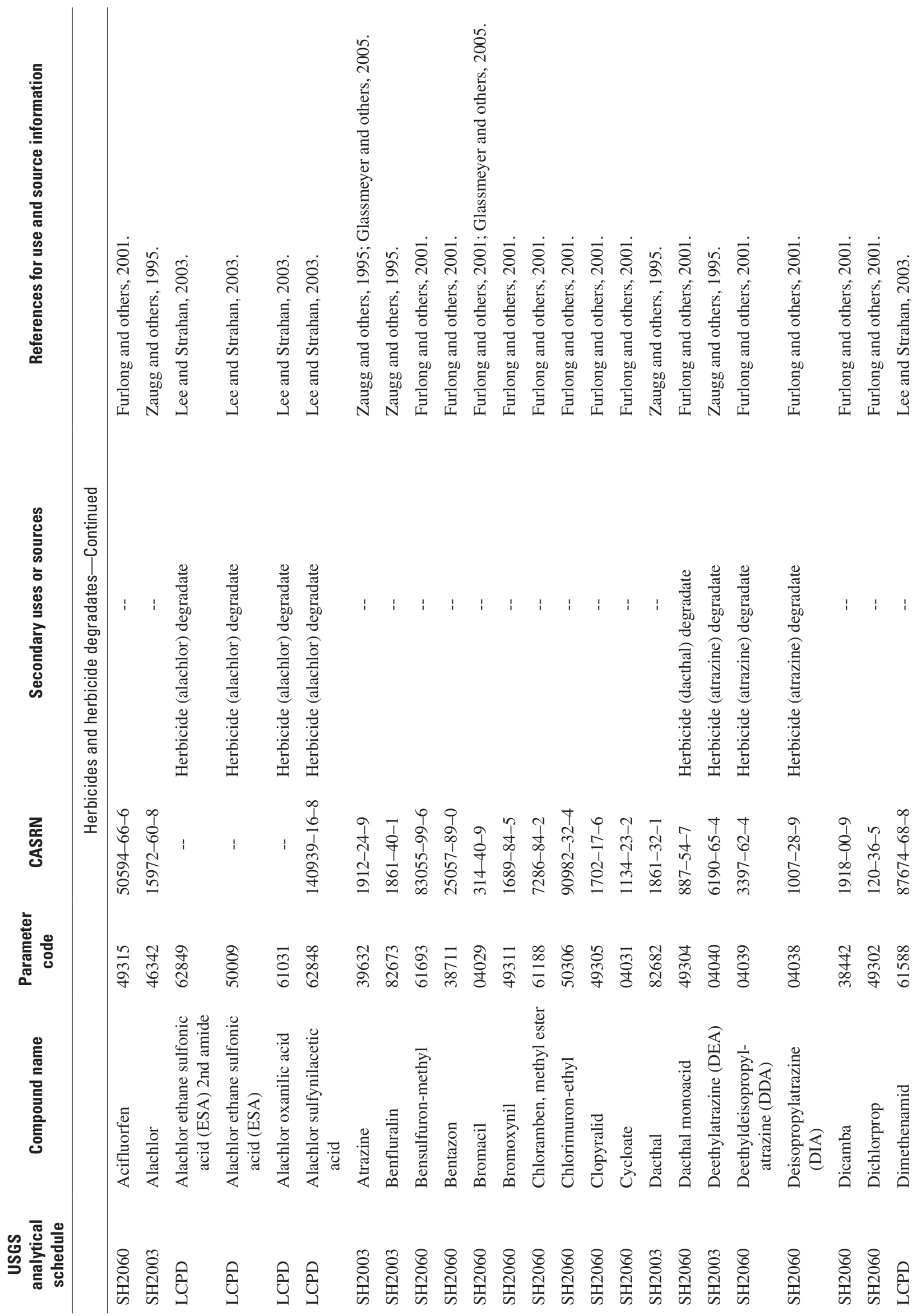



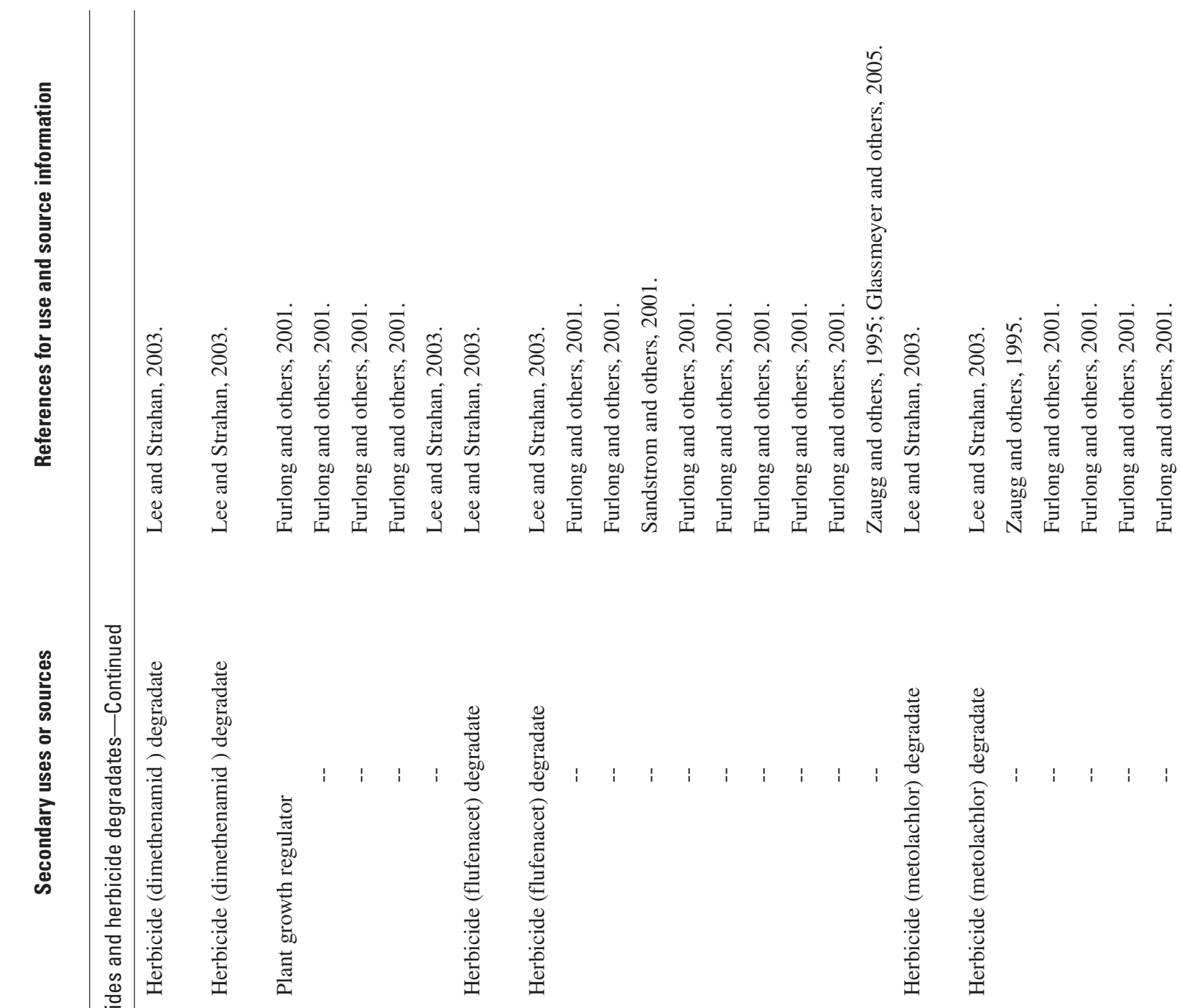

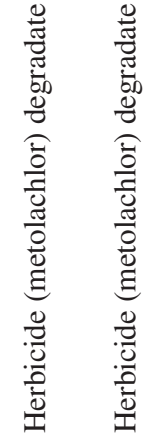

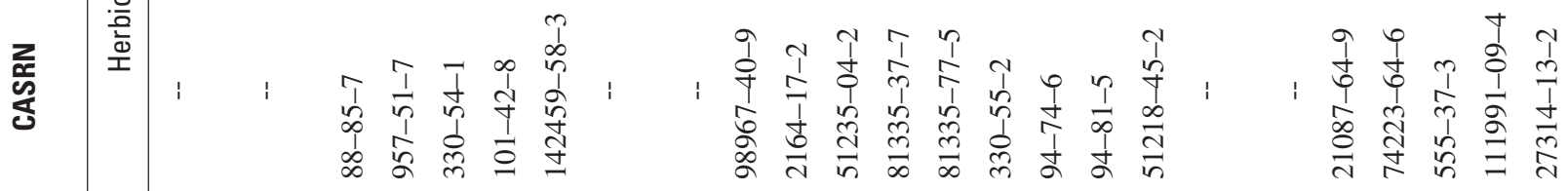

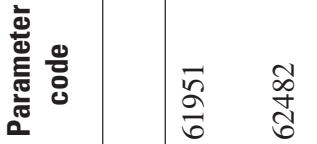

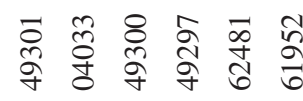

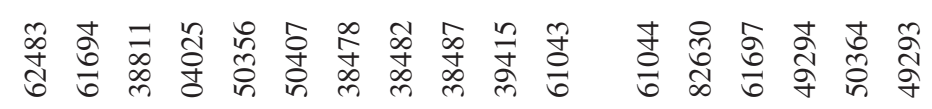
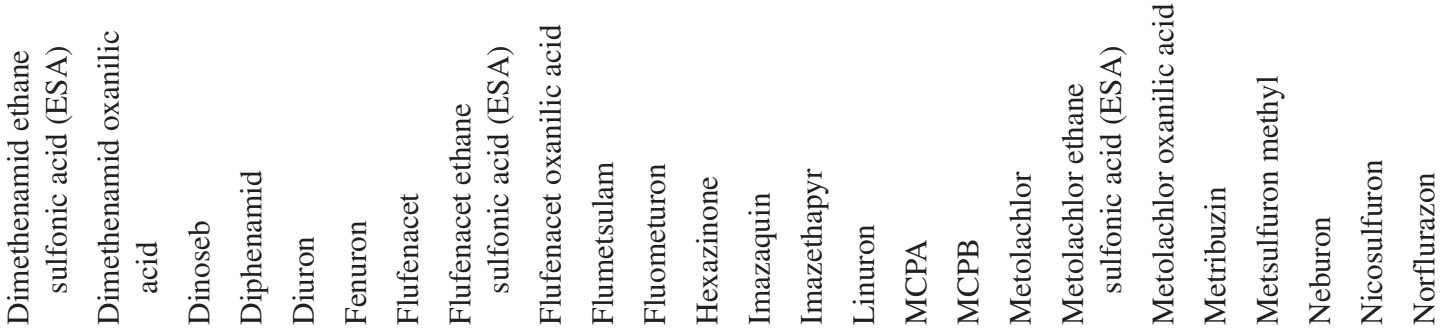


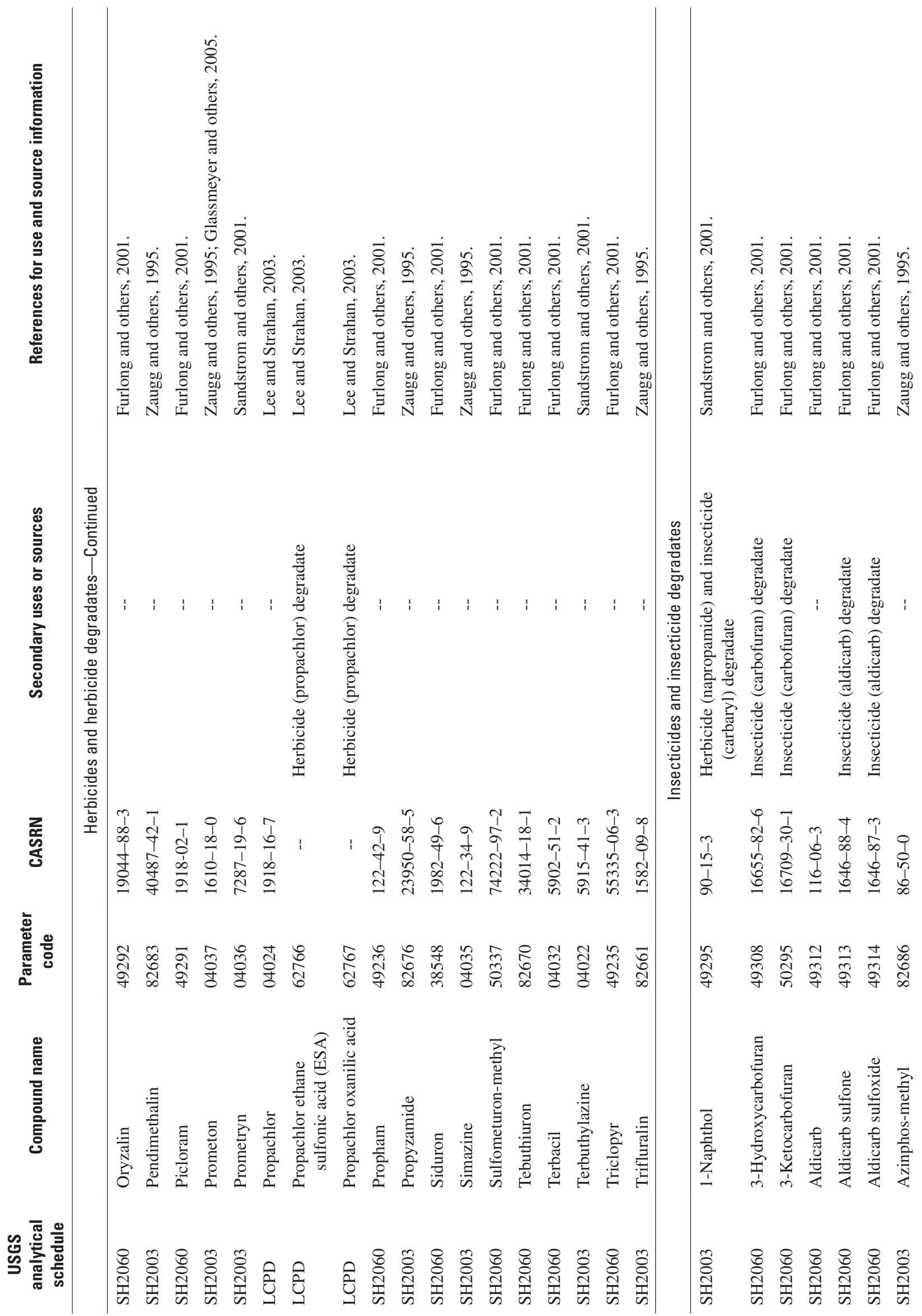




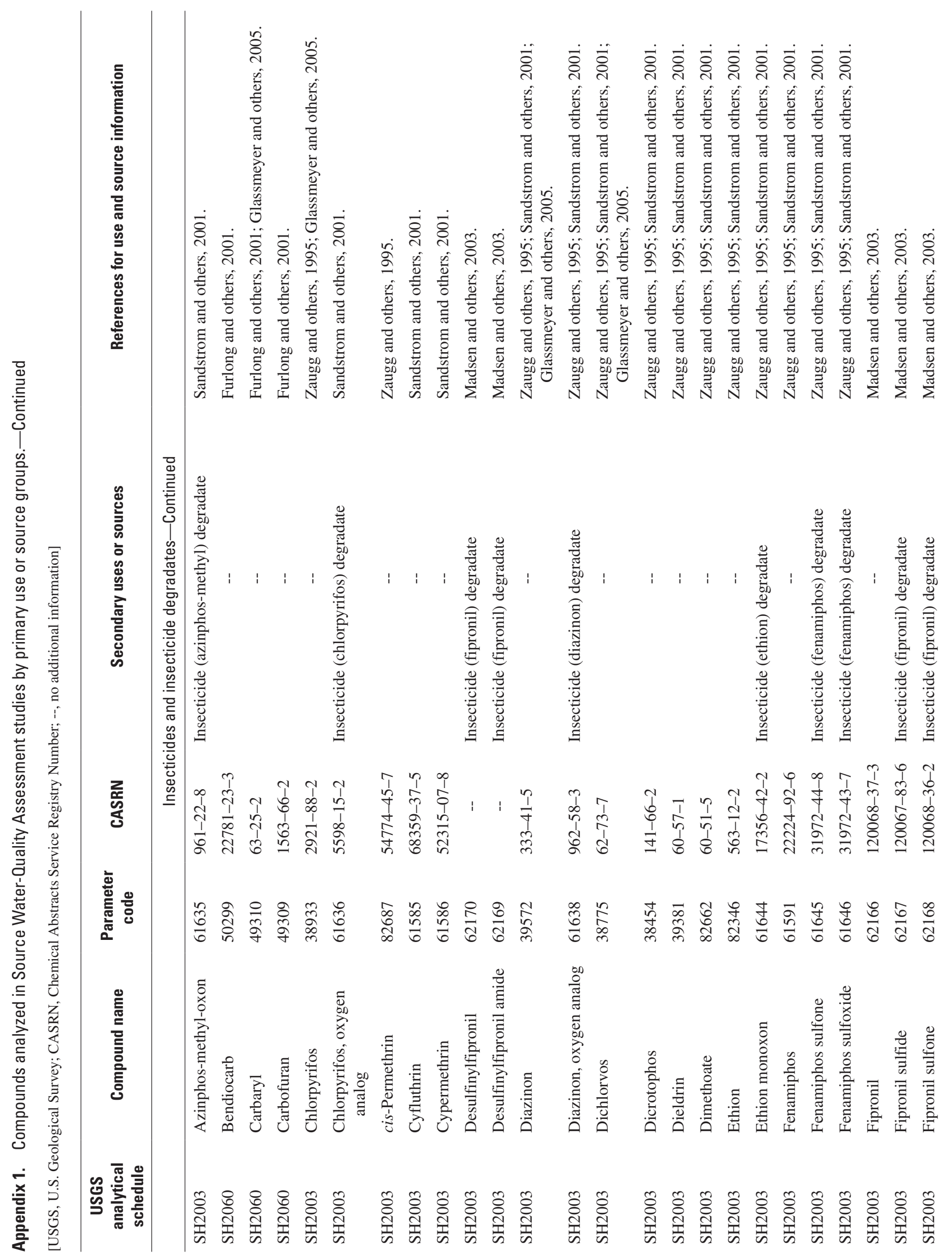




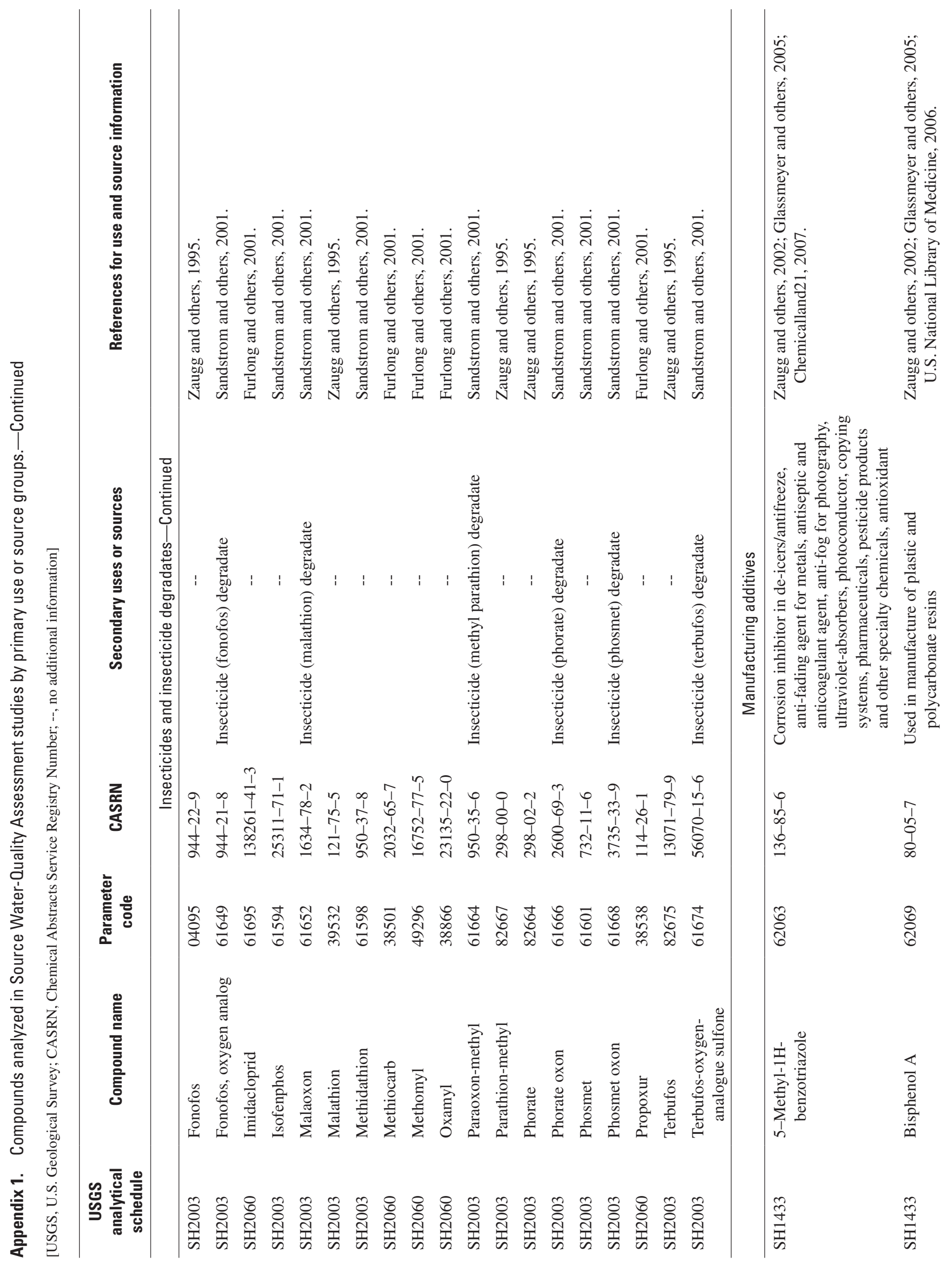




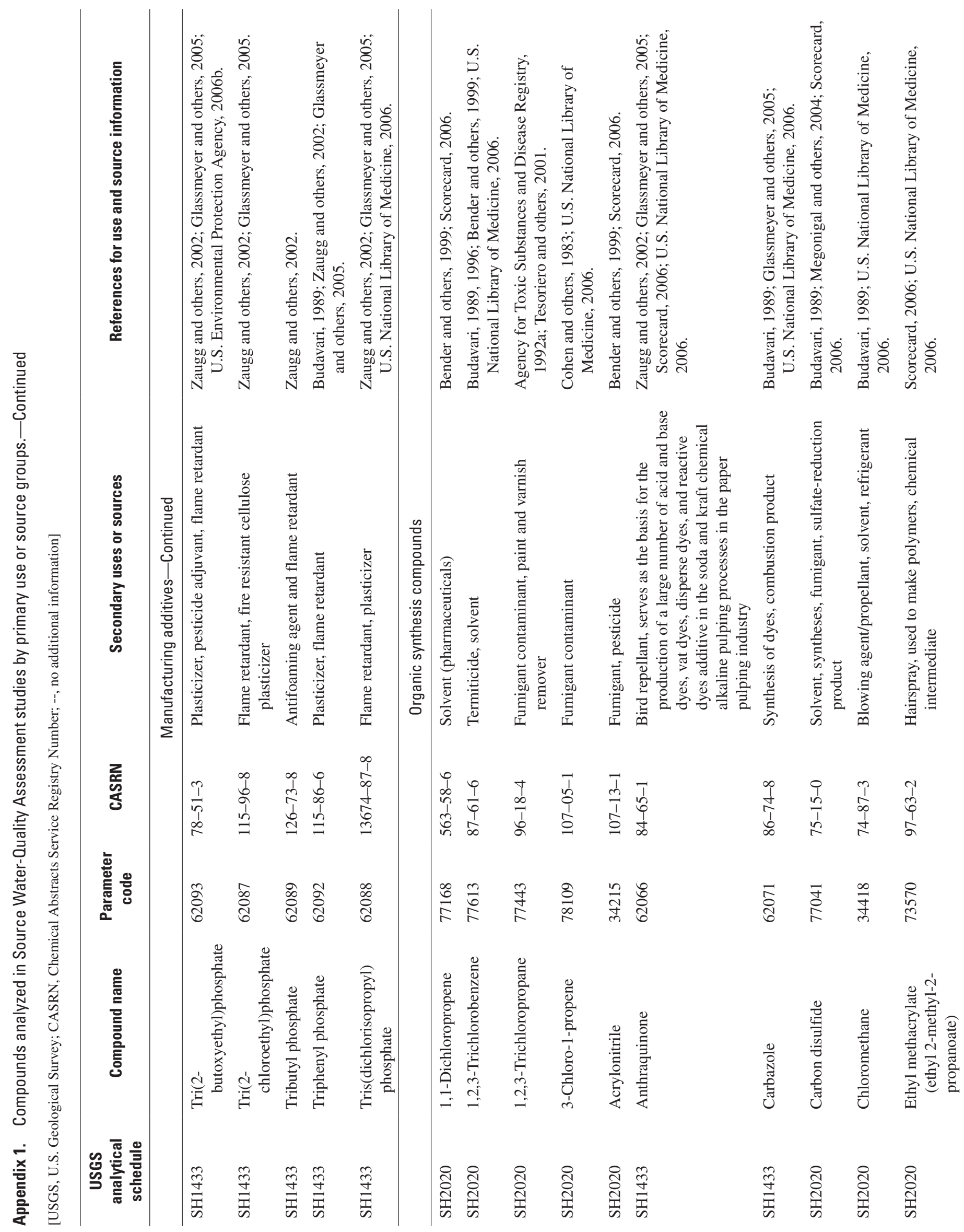




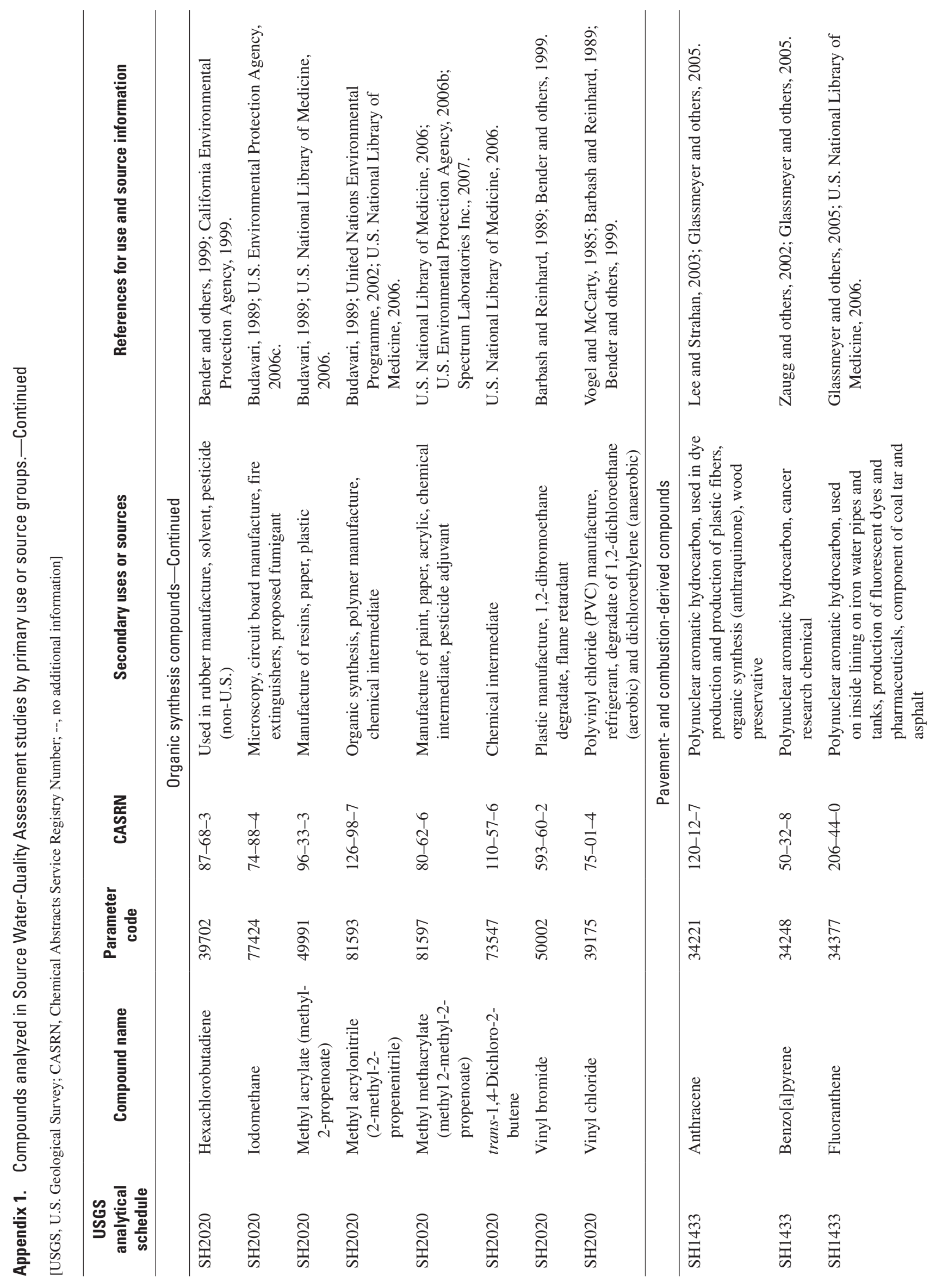




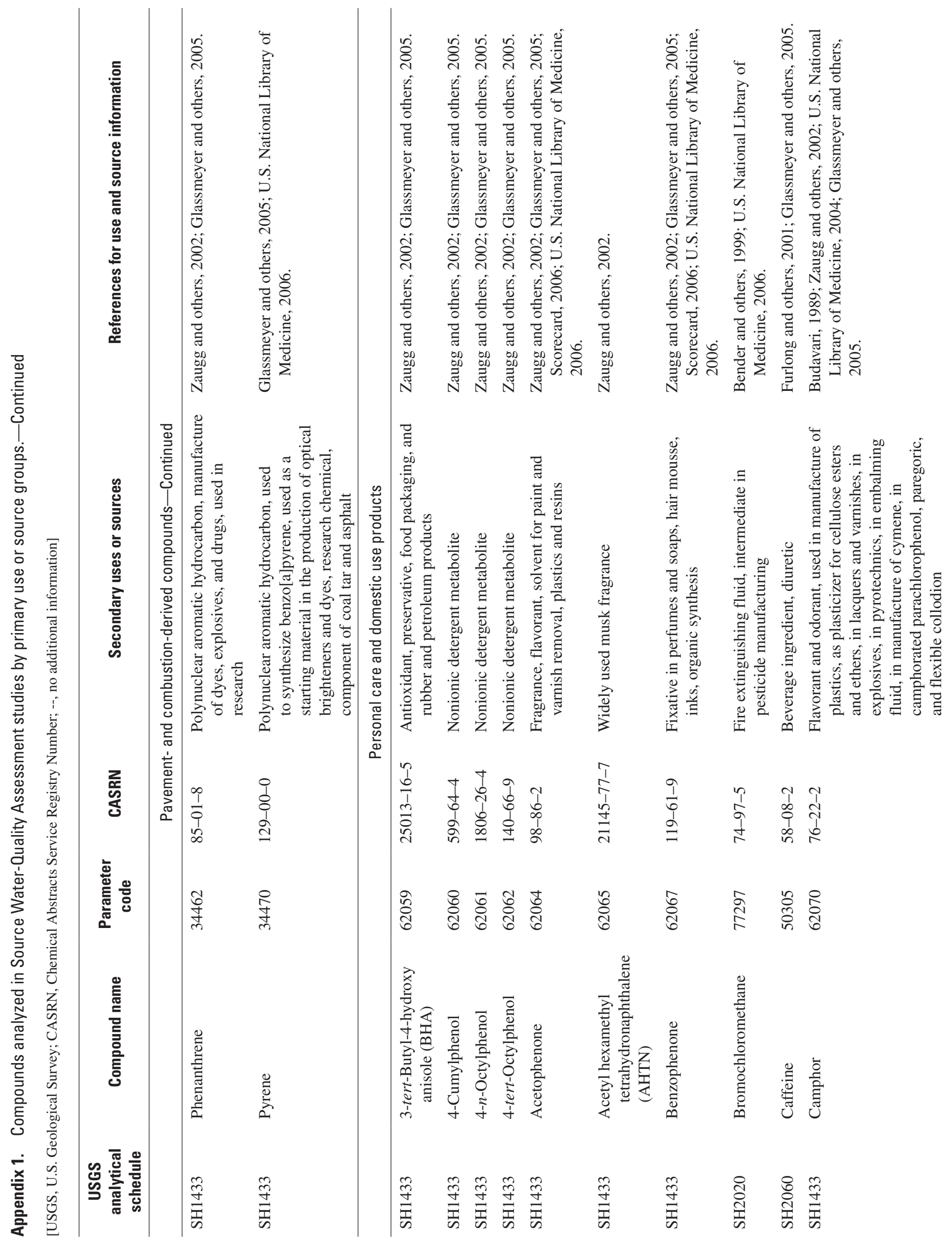




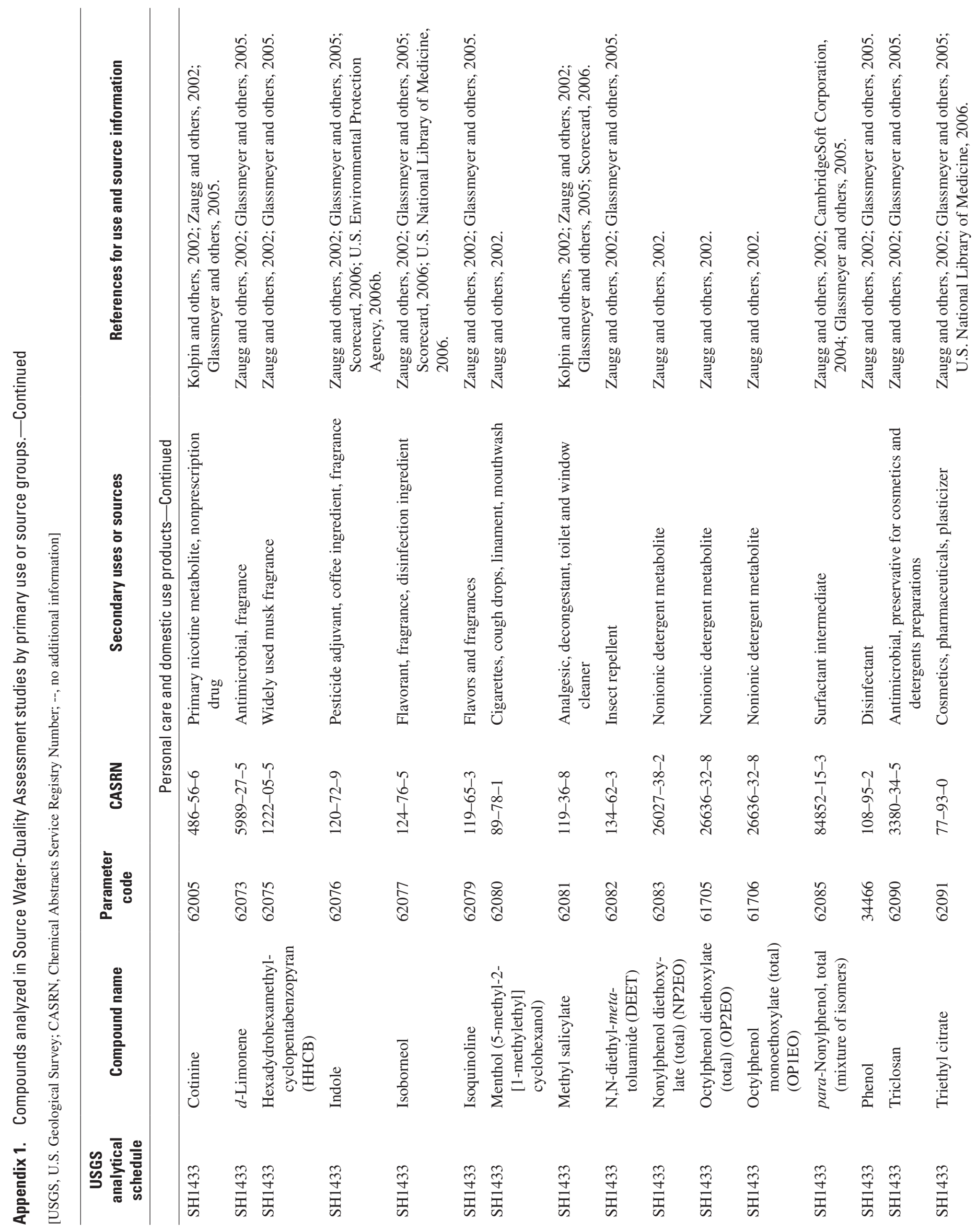




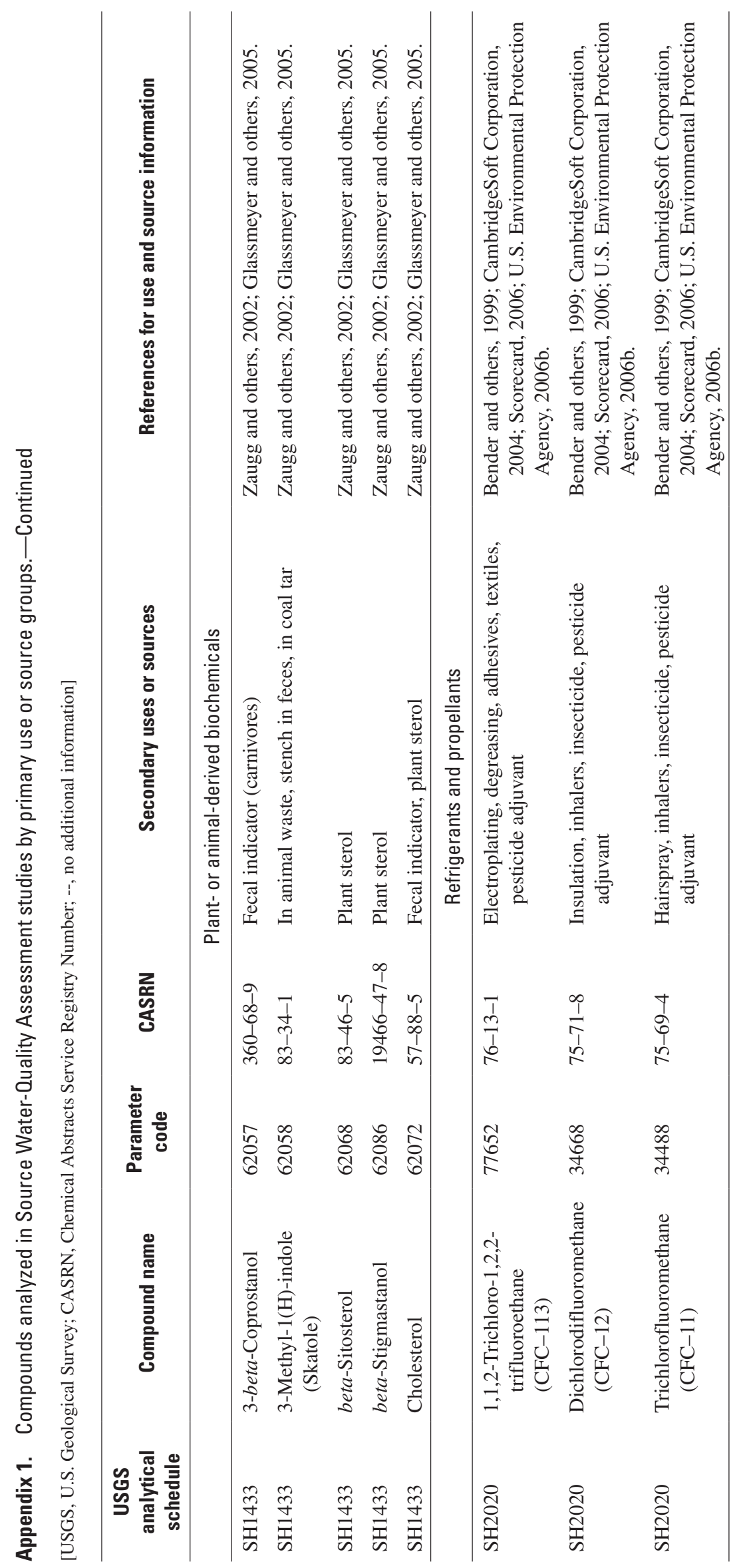

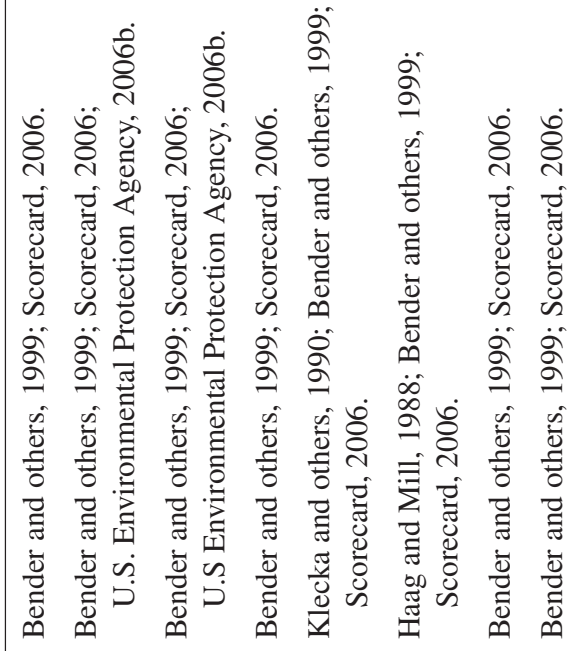

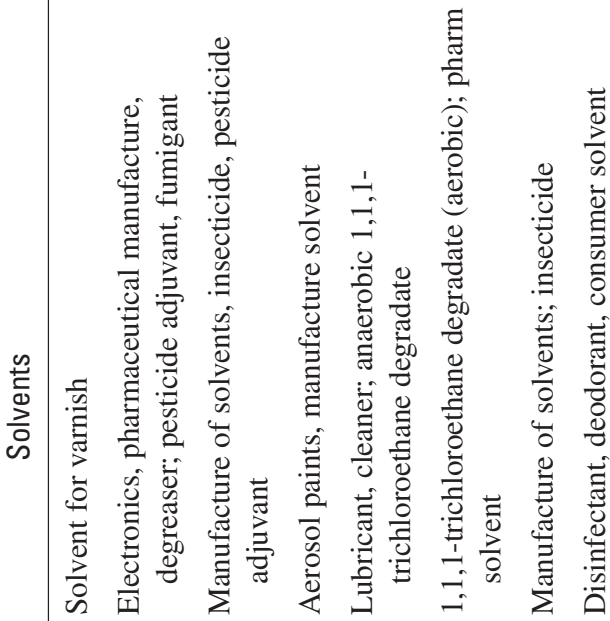

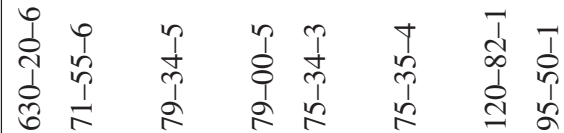

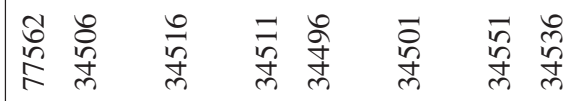

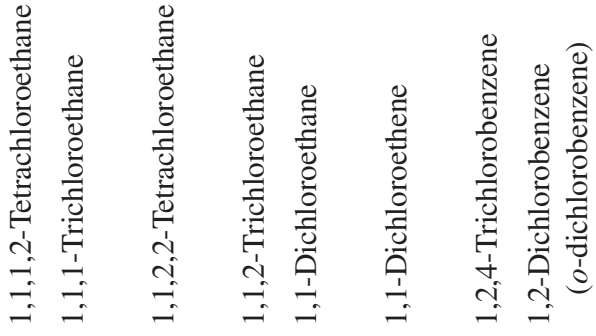

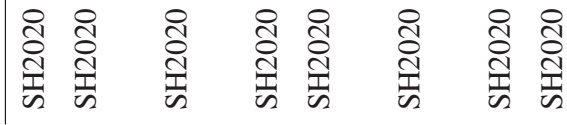




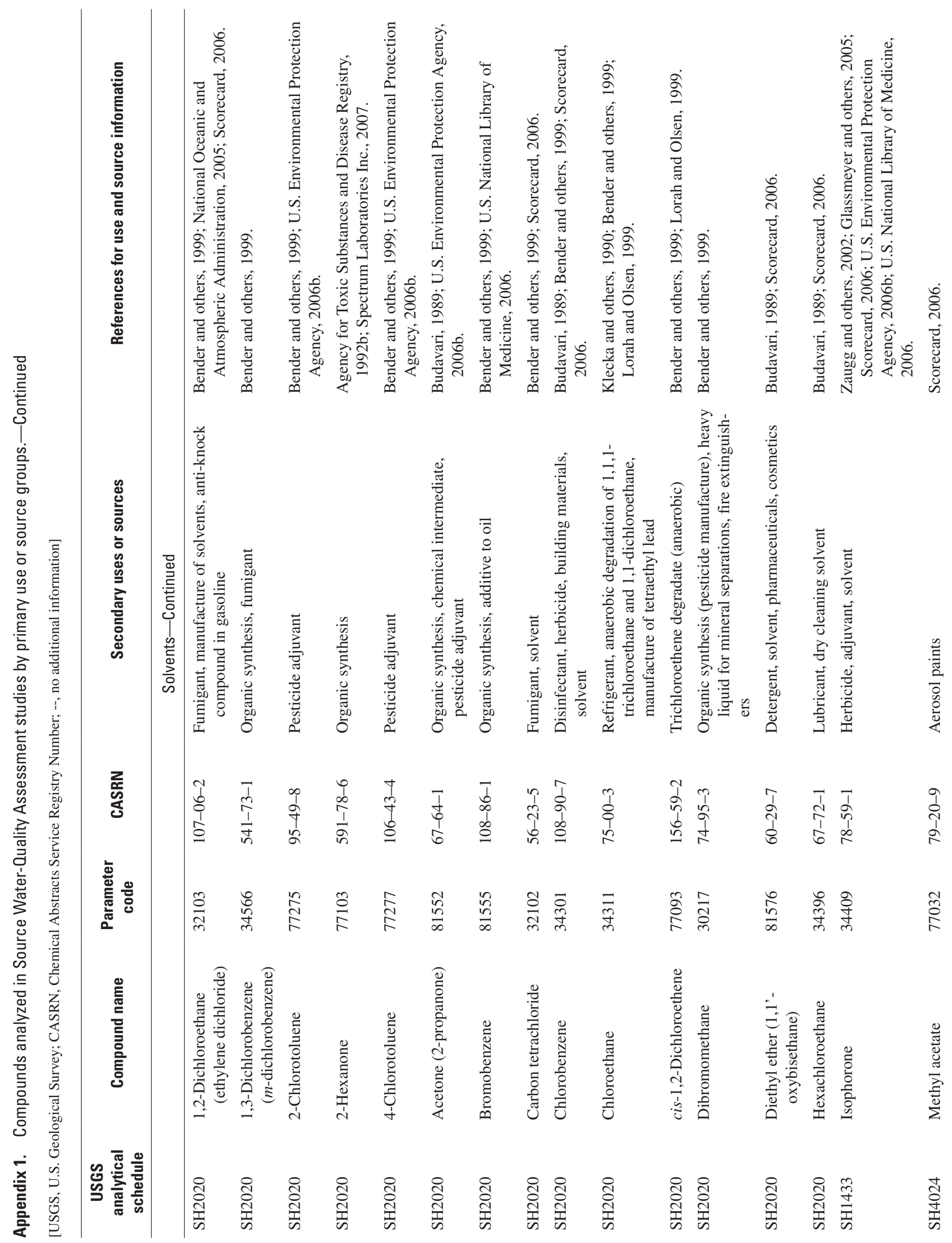




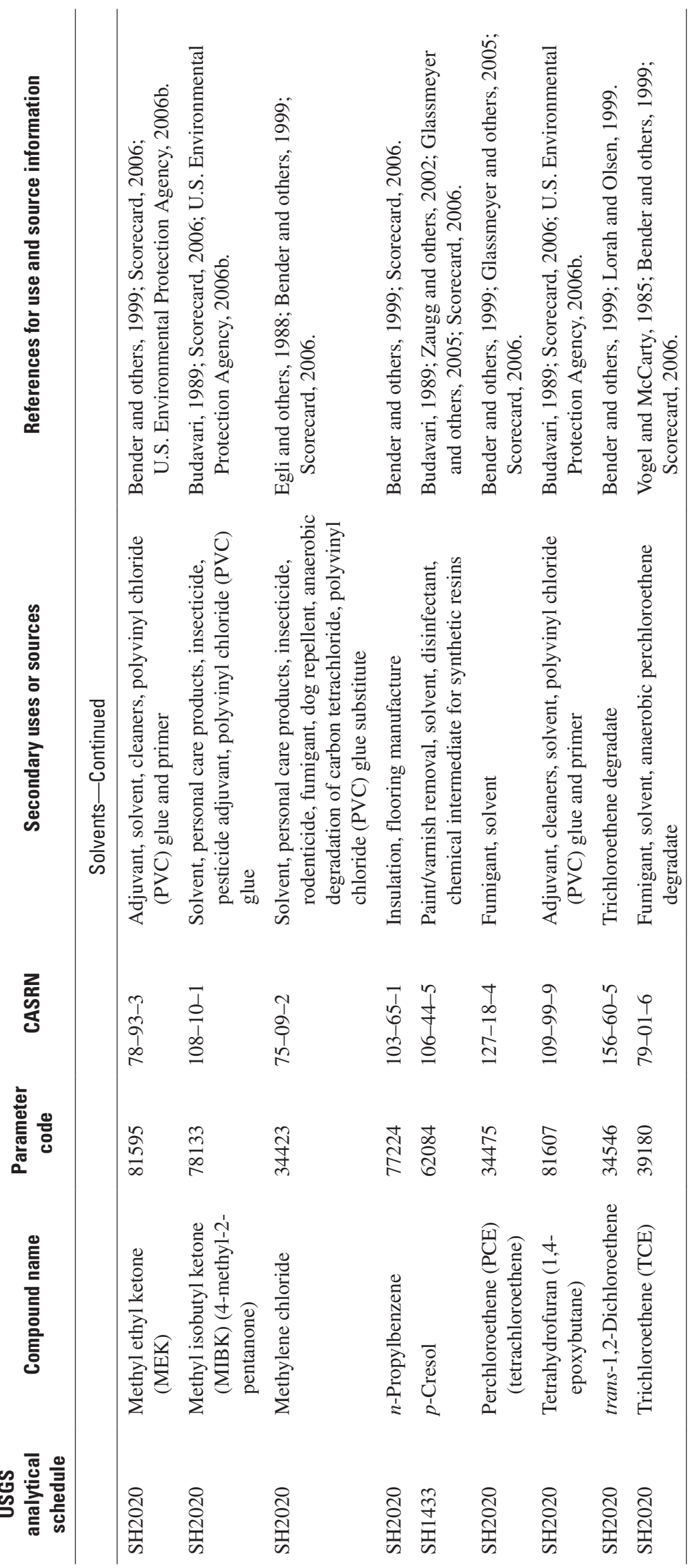


This page intentionally left blank. 
Manuscript approved for publication, April 16, 2007.

Prepared by the Helena Publishing Service Center.

For more information concerning the research in this report, contact:

U.S. Geological Survey

South Dakota Water Science Center

1608 Mountain View Road

Rapid City, SD 57702

http://sd.water.usgs.gov/

Information regarding the National Water-Quality Assessment

Program is available at http://water.usgs.gov/nawqa/ 
6 Printed on recycled paper 